\title{
Wage policies of a Russian firm and the financial crisis of 1998: Evidence from personnel data - 1997 to 2002*
}

\author{
Thomas Dohmen (IZA and DIW) \\ Hartmut Lehmann (University of Bologna; IZA; CERT; WDI and DIW)* \\ Mark E. Schaffer (CERT, Heriot-Watt University, Edinburgh; CEPR; WDI; and IZA)
}

This version: April 2007

\begin{abstract}
We use a rich personnel data set from a Russian firm for the years 1997 to 2002 to extend the analysis of internal labor markets to economies in transition. Our focus is on the effect of the financial crisis in 1998 and its aftermath on wages and the welfare of workers in the firm, providing evidence of how costs are distributed inside firms during such dramatic macroeconomic upheavals. We show that the firm does not refrain from cutting real wages. As it was a high wage firm before the crisis, it paid rents to many of its employees. Taking advantage of a high-inflationary environment and of a fall in outside options after the financial crisis, it is able to extract rents from its employees. The welfare losses are, however, not spread evenly across all employees, since the firm curbs earnings most for those who earned the highest rents, resulting in a strong compression of real wages. The fact that real wages and real compensation levels never recovered to pre-crisis levels even though the firm's financial situation was better in 2002 than before the crisis and the differential treatment of employee groups within the firm can be taken as evidence that market forces strongly influence the wage policies of our firm.
\end{abstract}

\footnotetext{
* The authors are grateful to David Brown, Tilman Brück, Vladimir Gimpelson, Rostislaw Kapeliushnikov, Alexander Muravyev and audiences at the Annual Scottish Economic Association Conference in April 2007, in Perth, and at the $8^{\text {th }}$ International Conference of the Higher School of Economics in April 2007, in Moscow, for comments and suggestions. Dohmen and Lehmann acknowledge financial support from the Deutsche Forschungsgemeinschaft (DFG) within the research program "Flexibilisierungspotenziale bei heterogenen Arbeitsmärkten" (DFGSP1169). Lehmann and Schaffer are grateful to the European Commission for financial support within the 6th framework project "Economic and Social Consequences of Industrial Restructuring in Russia and Ukraine" (ESCIRRU). Schaffer also thanks the William Davidson Institute and the U.S. Department of State (Title VIII) for financial support.

* Corresponding author: lehmann@spbo.unibo.it.
} 


\section{Introduction}

Observing how a firm adjusts its personnel policies in response to a large shock can yield vital insights about the nature of adjustment processes in labor markets. We analyze a rich personnel data set from a Russian firm for a period (1997 to 2002) that spans the Russian financial crisis in 1998, in order to shed light on crucial, but largely unresolved questions about the functioning of labor markets in general. For example, do firms adapt their wage policy to changes in labor market conditions? And if so, are all workers affected in the same way, or are incumbent workers shielded from external labor market shocks as early theoretical work on internal labor markets suggests (see Doeringer and Piore, 1971) ${ }^{1}$

In particular, we investigate how the firm adjusts employment, wages and other components of pay in response to the crisis, and study how the burden of the crisis is spread across the workforce. The very detailed information on employee remuneration and wage arrears enables us to provide a much clearer and more complete description of the mechanisms that are used to adjust earnings at the firm level than is typically possible. Such an analysis is important for at least two reasons: First, despite some attempts in the literature to assess the costs of economic crises on the workforce and on households (see, for example, Fallon and Lucas, 2002), we know virtually nothing of how these costs are distributed among employees inside firms during such dramatic macroeconomic upheavals. Second, although several studies have explored to what extent internal labor markets cushion incumbent workers from external labor market shocks (e.g., Baker et al., 1994, Lazear, 1999; Lazear and Oyer, 2004), it is still not well understood how workers' welfare is

\footnotetext{
${ }^{1}$ Doeringer and Piore (1971, p. 2) argue that workers in jobs that are filled by promotion or transfer from within are "shielded from the direct influence of competitive forces in the external market", but that the internal and external labor markets are connected at the ports of entry.
} 
affected by firm performance over the business cycle. Evidence on the degree to which firms are disciplined by external labor market conditions is mixed. Baker et al. (1994) find that workers are partly shielded against adverse shocks to external market conditions. $^{2}$ Lazear and Oyer (2004) report findings from the Swedish labor market, which indicate that external market conditions affect wages over the long run. The picture that emerges in the empirical literature suggests (1) that hiring wages track industry wages, but (2) that differences in hiring wages are persistent; indicating that market induced variations in marginal productivity are not fully reflected in wages of incumbent workers.

In all of the studies discussed above it is difficult to establish a direct link between shocks to (external) labor market conditions and changes of firm's personnel policies. This is because shocks have typically been small in most advanced Western economies during the last decades. If firms gradually adjust their personnel policies in response to such small but relatively frequent changes in external conditions, the impact of small shocks is typically difficult to measure and hardly observable in available data. If firms, on the other hand, sporadically react to accumulated shocks by major adjustments, it is difficult for the researcher to relate such a policy change to a particular external shock. Therefore, there is much insight to be gained by assessing how firms react to larger exogenous macroeconomic shocks, such as the financial crisis that occurred in Russia in $1998 .^{3}$ This crisis had severe consequences, leading to a substantial devaluation of the Ruble, a collapse of a large part of the private banking sector, a surge in inflation and interest rates, and liquidity problems, which adversely affected demand in the goods market.

\footnotetext{
${ }^{2}$ Baker et al. (1994) find cohort effects in starting wages which persist, implying that incumbent workers in their internal labor market are (partly) shielded from shocks to the marginal product.

${ }^{3}$ Large macroeconomic shocks are more frequently observed in developing and emerging economies. Other examples include the financial crises in Latin America and Asia in the 1990s.
} 
Our results show that these changes in economic conditions strongly influence the personnel policies of our firm. Real wages and real compensation fell substantially in the aftermath of the financial crisis. Employment levels at the firm, on the other hand, remained rather stable. ${ }^{4}$ The downward adjustment of earnings leads to persistent welfare losses among employees since real wages and real compensation levels had not recovered to pre-crisis levels by 2002 , even though the firm's financial situation was then better than before the crisis. These welfare losses were, however, not spread evenly across all employees. In fact, employees at the top of the earnings distribution tend to take the highest real wage cuts in relative terms, which is in part driven by external labor market conditions that limit the scope for cutting wages of employees at the bottom end of the firm's wage distribution. External conditions also appear to affect the firm's recruitment policy as hiring wages track market wages.

The firm, which was a high-wage firm prior to 1998, makes use of the high inflation that manifests during the financial crisis in order to extract rents from employees. It curbs earnings most for those who earned the highest rents, which results in a tremendous compression of real wages. Our findings also indicate that employees with long tenure have lower nominal wage growth, but face fewer wage arrears. ${ }^{5}$ The firm seemed to burden accounting staff with a disproportionate share of the costs of the crisis, as evidenced in a much higher incidence of wage arrears in 1998 than for other job categories and relatively low nominal wage growth between 1997 and 2002. It is possible that this personnel policy was a reaction to a rather loose

\footnotetext{
4 A policy that relies on "price" rather than "quantity" adjustments in response to adverse shock is typical for the Russian economy (see Boeri and Terrell, 2002; Earle and Sabirianova, 2002).

${ }^{5}$ Earle and Sabirianova (2002) investigate wage arrears with a matched employer-employee data set. However, the number of observed workers per firm in their study is small and only permits a crude estimate of the relative importance of intra-firm versus inter-firm determinants of wage arrears. They do not provide any evidence on the distribution of wage arrears across all workers within Russian firms, something that we are able to do, at least for the one Russian firm for which we have personnel data.
} 
firm attachment of accountants, which is demonstrated through their higher turnover rates than those of other employee groups. These higher turnover rates might have been a reflection of better outside options in the local labor market than for other employees.

The findings on real wage changes also contribute to the literature on wage rigidity. So far, this literature has documented compelling evidence that managers intentionally refrain from cutting nominal wages (Bewley, 1999). The resulting nominal rigidity is born out in personnel data (e.g., Baker et al., 1994; Wilson, 1996 and 1999; Altonji and Devereux, 2000; Dohmen, 2004). Clearly, nominal rigidity brings about real rigidity when there is zero inflation. In fact, Fehr and Goette (2005) provide evidence from personnel records showing that nominal rigidity even persists in a low growth environment with very low inflation, where it limits a firm's discretion to adjust real wage adjustment downwards (see Fehr and Goette, 2005). This indicates that motives for not cutting wages are strong and important. However, it is less clear that real rigidity would also stem from strong intentions for preserving real wages. ${ }^{6}$ Our evidence suggests that such intentions are weak: although the firm is reluctant to cut nominal wages, it does not refrain from substantially cutting real wages, taking advantage of a high-inflationary environment. We also complement the existing literature on real wage rigidity since we can - knowing the exact time period in which the 1998 financial crisis in Russia manifests - establish a direct link between the inflation shock and real wage adjustments at the firm.

The remainder of the paper is organized as follows. The next section provides a brief account of the financial crisis and introduces the firm under study. Section 3

\footnotetext{
${ }^{6}$ It is still controversial to what extent real wages are downward rigid. Card and Hyslop (1997) and Bauer et al. (2003) provide evidence for real wage rigidity using administrative micro data on wages .Baker et al. (1994) and Dohmen (2004) do not find that real wages are downward rigid in their analyses of personnel data.
} 
describes the personnel data set. Section 4 presents the main results of our analysis and establishes some robust evidence about the evolution of wages and total compensation in the firm over the period that encompasses the financial crisis. A final section concludes.

\section{The Russian financial crisis and the firm}

In November 1997 and during 1998 the Russian economy was confronted with two speculative attacks on the ruble. While the Central Bank of Russia (CBR) was able to successfully defend the ruble in the first episode, in August 1998 financial meltdown occurred and on August 17, 1998 the Russian government devalued the ruble, defaulted on domestic debt, and declared a 90 days moratorium on payment to foreign creditors. The classic ingredients of a financial crisis arising from a speculative attack on the currency were all present in the Russian case: ${ }^{7}$ (i) an exchange rate peg and the willingness of the CBR to defend it with foreign reserves; (ii) rising uncontrollable fiscal deficits with a prospect of their monetization; (iii) control of the interest rate by the CBR in a fragile credit market; and (iv) expectations of an impending devaluation of the ruble.

When the ruble came under speculative attack in 1998, with hindsight the most sensible political response probably would have been to let the ruble float. The Russian government and the CBR were, however, adamant not to go down this route. Since 1995 Russia had pursued a stabilization policy that was in particular based on the exchange rate as a nominal anchor. This strong anti-inflationary stance had brought inflation down to 11 percent, but at a high cost as the real exchange rate appreciated considerably, putting tremendous pressure on the import-competing

\footnotetext{
${ }^{7}$ For lucid discussions of the Russian financial meltdown, see Chiodo and Owyang (2002) and Kharas et al. (2001) and Summer's and Williamson's (2001) comments on the latter paper.
} 
manufacturing sector. A floating ruble in 1998 was considered by the Russian authorities as out of the question, since it might have reignited inflation and would have completely undone the effects of the anti-inflationary policies that had caused so much pain. Given this political position, the CBR defended the ruble until foreign reserves were exhausted.

The crux of the problems leading to the financial meltdown were rising public deficits and rising public debt that could not be contained in the medium run. Underlying the dynamics of public debt were structural problems related to tax compliance and tax collection. In addition, the price of oil started its slide in December 1997 and continuously fell in the first half of 1998, leading to less output and less tax revenue. Much of the public deficits had been financed with short-term government securities (so-called GKO's) since 1995. About a third of these GKO's were held by foreigners and a large amount of thus foreign held short-term debt came due in 1998. The attempt to swap most of these short-term securities for longertermed Eurobonds was only partially successful and given the essentially fixed exchange range the CBR could fight off the speculative attack on the ruble only through the depletion of foreign reserves.

The CBR tried to contain the currency crisis in the summer of 1998 also by slowing down the growth rate of the money supply and by twice raising the lending rate to banks from 30 to 150 percent. This rise in interest rates aggravated the country's debt problem as interest payments increased substantially. Consequently pressure on the currency grew even more as investors were convinced that Russian authorities would devalue to finance non-denominated debt. Because of the fragile nature of the Russian financial markets, the dramatic jump of the interest rate did not increase the supply of capital to firms, but actually made it nearly impossible for firms 
to raise capital for new investment projects, leading to a further fall in output, which exacerbated the debt problem even more. Attempts by international organizations to inject some liquidity in the Russian economy at that stage turned out be too little and too late.

Expectations of Russia's impending devaluation and default were also a crucial factor in the build-up of the crisis. The financial meltdowns in Asia alerted many investors to a possible default in Russia as did public relations disasters perpetrated by Russian authorities. The latter convinced investors that Russian policy makers were divided on how to solve the ensuing debt crisis and were thus more and more convinced of eventual devaluation and default (for details see Chiodo and Owygang, 2002).

The financial crisis had severe short-term consequences, leading to an upsurge of inflation, a collapse a large part of the private banking sector and a virtual stop of economic activities for some weeks. After this period, however, rising oil prices, a real depreciation of the ruble and a large fall in real wages set the Russian economy on a growth path, which is still ongoing. One main reason why the collapse of the banking had little effect on the real economy after the meltdown can be explained by the fact that private banks pre-crisis played mainly in the stock and bond markets and provided little lending capital to enterprises. In the run-up to and during the crisis, probably only few firms suffered because of decreased access to capital; however, firms did suffer because the overall lack of liquidity in the economy and a collapse in confidence of consumers and producers initiated a temporary standstill in economic activity and a reduction in demand for the products of firms.

The particular firm, for which we have data, is located in a provincial city in Russia and in the sector "machine building and metal works." After having converted 
production lines from Soviet times "nearly one hundred percent", according to the director general of the firm $(\mathrm{CEO})^{8}$, it produces well equipment for gas and oil production and smith-press equipment. More than ninety percent of its production is destined for the Russian market. It has locally no competitors, but nationally it has to compete with more than 5 firms, among them importers from the European Union. The firm was founded in the early fifties of the last century and privatized in 1992. A decade later, in 2002, more than half of the shares were owned by managers and workers, about twenty percent by former employees and roughly a quarter by other Russian entities. While there is collective bargaining at this firm on paper, trade union representatives have virtually no influence on wage policy and wages are set unilaterally by top management. Real output, capacity utilization and profits were all at a trough in 1998, recovered slightly in 1999 and then took off dramatically after the year 2000 .

How was the firm affected by the financial crisis? As we have seen, leading up to the crisis there was a sharp drop in oil prices. The ensuing drop in oil production affected the demand for its oil equipment negatively. In addition, even before the fall in oil prices the real appreciation of the ruble made it difficult for the firm to compete with importers. From the interview with the firm's director general it is clear that the shortage of lending capital was less relevant for this firm than the drop in oil production and the high real exchange rate of the ruble. The devaluation of the ruble on August 17, 1998 brought a brief respite to the industry. This is also evident from Figure 1, which shows both the profitability of our firm and the profitability of the sector, in which the firm operates. According to the director general, the "[firm] became competitive in terms of price". Dramatically falling real wages, not

\footnotetext{
${ }^{8}$ Source: Interview with the director general of the firm in the spring of 2002.
} 
mentioned by the top manager, did certainly also their part, as we will see in what follows. By the spring of 2002 (the time of the interview), this advancement in competitiveness had evaporated, and EU firms had increased their market share in the market segment, in which the firm operates. Due to the high oil price demand for oil drilling equipment has, however, remained strong, which explains why profits and capacity utilization rates remained high at our firm even after 1999.

The firm whose wage policies we discuss can be considered unusual for the sector "machine building and metal works" and for the oblast where it is located, certainly as far as its wage policies are concerned. Figure 2 shows a real monthly wage paid by our firm in 1997 and 1998, which is more than 50 percent higher than the wage paid in the sector and more than double the wage paid in the region. In the aftermath of the crisis we see a precipitous fall of the real wage in our firm, while wages in the economy at large, the region and the sector show a more moderate fall. After the crisis the real wage profile in the firm stays flat but shows a continuous rise for the three aggregates. By 2003 the average real wage in the economy and the sector exceed that in our firm. It is noteworthy, though, that the average regional wage remains below the firm's average wage even in 2003.

\section{The personnel dataset}

We created an electronic file based on records from the personnel archive of the firm, and constructed a year-end panel data set for the years 1997 to $2002 .^{9}$ We have records of all employees who were employed at any time during this period. ${ }^{10}$ The data contain information on individuals' demographic characteristics such as gender, age, marital status and number of children, on their educational attainment, retraining

\footnotetext{
${ }^{9}$ We have also wage data for all months in 2003 except for December. However, since we also lack data on yearly bonuses for 2003, we do not use the compensation data for 2003 in this paper.

${ }^{10}$ Information for top managers is missing for reasons of confidentiality.
} 
and other skill enhancement activities before joining the firm and during tenure at the firm. We also know the exact date when each employee started work at the firm as well as his/her complete working history before that date. We can trace each employee's career within the firm since we have information on the current position and on all previous positions and the periods when each of them was filled out by the employee. In addition we also know whether someone worked full-time or part-time. For those who separated from the firm we can distinguish between voluntary quit, transfer to another firm, individual dismissal, group dismissal and retirement.

In Russian firms the workforce is often divided into five employee categories: administration (i.e. management) which we label "managers"; accounting and financial specialists whom we label "accountants"; engineering and technical specialists (including programmers) whom we subsume under the term "engineers"; primary and auxiliary production workers, whom we label "production workers"; and finally, service staff. ${ }^{11}$

For the years 1997 to 2002 we have monthly wages averaged over the year, and information on the three types of bonuses paid to the workforce: (1) a monthly bonus amounting to a fixed percentage of the wage; (2) an extra annual bonus whose level depends on "the results of the year" (i.e. this bonus is a form of profit sharing); (3) an annual bonus labeled "other bonus". While production workers never receive a monthly bonus, the bonus labeled "other bonus" is paid to production workers only. Wages are reported by the firm as the employee's average monthly wage in rubles for the year (or fraction of the year, if not employed for the full 12 months), with no adjustment for inflation. The monthly bonus is reported as a percentage of the average monthly wage, and the corresponding ruble figure is recovered by applying

\footnotetext{
${ }^{11}$ Only production workers are subdivided into levels, primary production workers having eight and auxiliary production workers having six levels.
} 
the percentage to the nominal monthly wage. The other two bonuses are reported in nominal rubles. The inflation rate in Russia during this period was irregular and sometimes quite high - the price level more than doubled between the start of the financial crisis in July 1998 and April 1999, and was 0-2\% per month before and after - and so some care is required to construct appropriate deflators. Because nominal average monthly wage and the nominal monthly bonus are averages for the year, they are deflated into 1997 constant rubles using an annual average CPI, i.e., the average price level for the year relative to the average price level in 1997. The other two bonuses are paid around the end of the year, and so these are converted into 1997 constant rubles using the CPI price level for December of the corresponding year, i.e., the December price level in that year relative to the average 1997 price level. $^{12}$

\section{Main Results}

\section{Employment}

Table 1 shows that employment grew steadily from 3032 employees to 3221 employees during the observation period from January 1997 until December 2002, with the exception of the post-crisis year 1999. Yet, the composition of the workforce

\footnotetext{
${ }^{12}$ We have available monthly data on CPI inflation in Russia overall and in the oblast where the firm is located. In this paper we work primarily with average monthly wages, and so we compare average annual inflation in the oblast with national rates. This shows that inflation in the oblast is very similar to national inflation:
}

$\begin{array}{ccc} & \text { Russia } & \text { Oblast } \\ 1997 & 15.4 & 14.0 \\ 1998 & 38.1 & 38.7 \\ 1999 & 98.6 & 97.9 \\ 2000 & 20.8 & 20.4 \\ 2001 & 21.6 & 19.1 \\ 2002 & 16.0 & 14.5\end{array}$

These indices are based on average monthly price levels calculated using monthly inflation rates. Over the 1997-2002 period, the cumulative price indices diverge by less than $3 \%$. Results using wages and bonuses deflated by the national CPI are therefore essentially identical to those using the oblast CPI. We use the former in what follows. 
hardly changed throughout the period. There is a small increase in the share of workers compensated by negligible falls in the shares of service staff, engineers and accountants, with managers retaining the same share of 3.8 percent throughout.

Turnover rates, calculated as the sum of hires and separations during a given year normalized by the stock at the beginning of the year, were particularly large in 1997 and 1998 (see Table 2). After the crisis they fell quite dramatically, in 2002 reaching less than half the level of 1997 . This secular pattern holds for all employee categories, but turnover was especially turbulent for accountants, production workers and service staff and much more modest for engineering staff throughout the period. In addition, while there was a large turnover of managers in the crisis year, there are few managers who enter or leave the firm after 1998.

The fall in turnover rates after the crisis year of 1998 comes about because of a fall in separation and hiring rates (see Table 2). The bulk of the separations (about 80 percent) throughout the period are voluntary quits. Therefore the fall in the separation rate in the post-crisis year suggests that the financial crisis restrained many employees from quitting. The firm's employees seem to have been continuously confronted with a more limited array of outside options compared with the situation

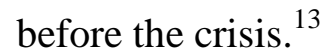

In order to see what drives separation rates, we estimate Cox proportional hazard models in which we specify calendar time as the duration variable (cf. Dohmen and Pfann, 2004) and assume the same baseline hazard for all five employee specific categories. ${ }^{14}$ The results are shown in Table 3. Specifications (1), (3) and (5)

\footnotetext{
${ }^{13}$ Many workers in our firm saw these outside opportunities in the "suitcase trade", travelling between Russia and, e.g., China or Turkey and buying and selling certain types of goods informally. Such opportunities were severely reduced after the crisis, resulting in a dramatic fall of the number of "suitcase traders" throughout Russia (Eder, Yakovlev and Çarkoglu, 2003).

${ }^{14}$ An extension of these models allows for employee category specific baseline hazards. The estimates of such models, available on request, are virtually identical to the estimates of the presented models in
} 
differ from (2), (4) and (6) only insofar as the second set of specifications controls for the position in the employee category specific wage distribution. The baseline hazard for specification (1), plotted in figure 3, shows a clear downward trend over the entire period, and is roughly twice as large before and during the crisis as in the years 20002002. It is striking that in 1997 and 1999 the hazard shoots up at the end of year but that the jump in the hazard rate in 1998 takes place in the two months immediately following the crisis. We estimate hazard rates for the entire period and for the two sub-periods 1997-1999 and 2000- 2002.

Tenure plays a minor role as far as separations from the firm are concerned. Employees with tenure up to two years and those who have been with the firm between 25 and 30 years have substantially lower hazard rates than workers in the reference category who are in their $10^{\text {th }}$ year of employment at the firm; otherwise the tenure hazard profiles are rather flat. It is also noteworthy that the highlighted tenure effects are only significant in the first sub-period. In the period of high turnover educational attainment only weakly affects the separation hazard, while between 2000 and 2002 employees with more than basic education have a higher propensity to leave the firm than those employees with lowest educational attainment. The very young and those who have reached retirement age have a much higher separation rate than those employees who are between 30 and 35 years of age. The age hazard profiles are also striking insofar as workers over the age of 45 but still far from retirement, have a substantially lower propensity to separate from the firm than other age groups. Female employees have higher separation rates than their male counterparts, especially in the period of high labor turnover. On the other hand, employees with children are more reluctant to leave the firm. specifications of the Cox model. 
In both periods, service staff and engineers remain more with the firm than production workers and accountants; while in the years 2000 to 2002 there is only one manager who exits. When turnover is high, hazard rates are highest for those employees located in the polar deciles, while in the second period only persons in the lowest decile have a higher propensity to leave. In addition, ceteris paribus, employees in the seventh and eight deciles seem to be more reluctant to leave the firm.

\section{Wage structure}

Figure 4 plots kernel density estimates of the real wage distributions for different employee categories in 1997. It is immediately obvious that there is substantial heterogeneity in wages within employee categories. Moreover, real wage distributions for different employee categories overlap, so that many high paid production workers, for example, earned at least as much as lower paid managers. Service staff had the lowest mean wages in 1997 followed, somewhat surprisingly, by engineers, then production workers and accountants. Managers had the highest wages on average. This ranking of employee group-specific wage distributions remains unchanged throughout the observation period.

Estimates from OLS regressions of log wages in 1997, reported in Table 4, show that service staff earn on average 52 percent less than production workers, while the latter earn around 6 percent more than engineering staff. Accountants and managers earn approximately 50 and 95 percent more than production workers (see column (1)). The estimated coefficients from the augmented Mincer wage regression in column (1) also illustrate that workers with longer tenure and more education receive higher wages. Women earn significantly less than men, while marital status and the number of 
children do not have a significant impact on wages. The mentioned factors significantly determine the wage structure throughout the observation period, but the size of the effects is attenuated over time. For example, while employees with university degree earned about 13 percent higher wages than employees with only basic education (conditional on employee category) in 1997, their wage mark-up falls to only 11 percent in 2002 (see Table A1 in the Appendix). It is also striking that wage tenure profiles are much flatter in 2002 than in 1997. In addition, the gender wage gap is reduced between 1997 and 2002 from 27 to 15 percent, and, with the exception of managers, wage differences between employee categories have diminished as well by 2002, an issue to which we return later. Columns (2) to (6) show wage regressions for the different employee categories.

Quantile regressions (reported in Table A2 in the Appendix) show that the effect of tenure on wages is similar across the entire wage distribution in 1997. As far as the impact of educational attainment is concerned, we see two results. Employees with higher education (university graduates) have a positive relative return throughout the distribution, while for the other educational groups the highest premia are in the lowest deciles. The gender wage gap is substantially larger in the lower half of the distribution and especially attenuated in the 9-th decile. Relative to production workers service staff encounters a growing "wage penalty" as one goes from lower to higher deciles. It is noteworthy that engineers earn the same as production workers if they find themselves in the lower tail of the distribution but earn less from the third decile onwards. For accountants the "mark-up" over production workers falls from 90 percent in the $1^{\text {st }}$ decile to 20 percent in the $8^{\text {th }}$ decile, while for managers the mark-up falls from 185 percent in the $1^{\text {st }}$ decile to 59 percent in the $9^{\text {th }}$ decile. The results of 
quantile regressions for $2002^{15}$, though qualitatively in line with the results for 1997 , show attenuated differences in the impact of the above discussed covariates on log wages across the wage distribution. This is not surprising given the strong compression of the wage distribution during the studied period.

Real total compensation at our firm developed similarly, since the share of wages, unsurprisingly, made up the lion share of total income in all years as Table 4 shows. ${ }^{16}$ In the crisis year of 1998 , the wage share rose to more than 90 percent of total income and then declined to slightly more than three quarters of total income in 2002. The shares of all bonus components fell in the crisis year but then more than recovered in the remaining years.

\section{Nominal and real rigidity}

An inspection of the data reveals that the firm never cuts nominal wages. ${ }^{17}$ Real wages, however, fall markedly in the aftermath of the financial crisis in 1998. Figure 5 and Figure 6 show that real wages and real monthly compensation (measured as the sum of real monthly wages and the monthly share of all real bonus payments for the year) in the upper half of the respective distribution fell most, both in absolute and in relative terms, and recovered least in post crisis years. As a result, kernel density estimates of the wage distributions in 2002, which are plotted in Figure 7, are clearly to the left of the real wage distributions in 1997 , for all employee categories. The real wage distribution also seems more compressed.

\footnotetext{
${ }^{15}$ These results are not shown here but are available on request from the authors.

${ }^{16}$ The estimates of the quantile regressions on log total real compensation are also very similar to the results for the quantile wage regressions. Several difference are, however, worth commenting on: When bonus payments are added to wages, engineering staff and production workers have nearly the same mark-ups over service staff in 1997. This convergence is, however, reversed in the year 2002. The mark-ups of managers, on the other hand, are larger in both polar data points when total compensation is estimated.

${ }^{17}$ Sources close to the firm's top management told us that the firm never contemplated to cut nominal wages since such cuts might have resulted in even higher quit rates than the ones observed before the crisis.
} 


\section{Who bears the burden of the shock? Individual wage mobility}

Even though average real wages fall, not all employees are affected by the crisis in the same way. This becomes evident from Figure 8 which plots the kernel density estimate of the distribution function of real wage growth between 1997 and 2002. These heterogeneous real wage growth rates cause substantial relative wage mobility inside the firm as transition rates between quintiles of the wage distribution in 1997 (the origin state) and in 2002 (the destination state), calculated for the balanced panel of those who were continuously employed during the entire period, in Table 5 reveal. $^{18}$ For example, only 35 percent of all employees who found themselves in the third quintile of the wage distribution in 1997 remain there in 2002, while 41 percent move up in the wage distribution and 24 percent move down. This pattern is observed for all employment groups, but is particularly marked for production workers. ${ }^{19}$ The transition patterns are also very similar albeit slightly stronger for total compensation. Thus, the firm substantially realigned real wages and total compensation during the inflationary period following the financial crisis, especially for the core group of the firm, the production workers.

In order to assess whether particular characteristics systematically determine relative wage growth, we regress the growth rate of real wages between 1997 and 2002 on various individual characteristics and job characteristics. We restrict the sample to full-time employees who were continuously employed during the entire observation period.

\footnotetext{
${ }^{18}$ Some scholars studying Russian labor markets in the first half of the 1990's maintained that there was substantial relative wage mobility in the economy at large (see, e.g. Commander et al., 1995).

${ }^{19}$ Transition matrices showing wage and compensation dynamics for different employee categories are available from the authors on request.
} 
Table 7 contains the regression results with three different specifications of the wage growth equation. Specification (1) estimates wage growth as a function of a cubic in tenure and age, dummies for highest educational attainment, and demographic dummies. This specification assumes that wage growth does not depend on an individual's position in the firm-level wage distribution in 1997. The tenurewage growth profile looks as follows: tenure and wage growth are inversely related up to approximately 20 years, between 21 and 30 years of tenure wage growth remains flat at roughly minus 22 percent and then turns slightly more negative for longer-tenured employees. On this measure, the firm seemed to favor those employees who have been hired more recently. Holding other factors constant, female employees earn a substantial premium if the results of the model in column 1 are to be believed.

Specification (2) adds dummies for the employee's position in the firm-level wage distribution in 1997. This model might still be too simplistic, since it assumes that all employees were confronted with the same wage distribution in 1997. As we have seen, though, the locations and the spreads of the wage distributions for the 5 employee categories were very different in 1997. To take account of this, specification (3) adds controls for the location in the employee category-specific wage distribution and dummies for employee categories. The results of specifications (2) and (3) are similar, and we concentrate our discussion on the results of specification (3).

The impact of tenure, while somewhat attenuated, remains negative throughout the tenure distribution. Secondary professional and higher educational attainment imply higher wage growth, while female employees experience smaller wage growth than their male counterparts. The latter result, reversing the estimated 
wage growth premium for female employees in specification (1), can be explained by the fact that women find themselves in 1997 in employee and wage segments that exhibit the highest growth throughout the reported period.

The coefficients on the decile dummies strongly confirm our contention that employees positioned in 1997 in the lower deciles of their respective wage distribution experienced relative gains in the reported period. Location in the lower four deciles implies stronger wage growth than for those employees who were positioned in 1997 in the median decile. These relative gains are monotonically decreasing as we go from the bottom to the $4^{\text {th }}$ decile. In contrast, employees positioned in 1997 in the highest four deciles of their wage distribution are confronted with relative wage losses. Relative to production workers, service staff and engineers have wage gains over the period, while accountants and managers have wage losses albeit of a small order.

In Table 8 we remove the assumption that wage growth is equiproportionate for each quantile across all employee categories, and estimate wage growth regressions for each employee category separately. The results show clear differences in the returns to the various deciles for the five employee categories. In particular, the relative returns for service staff show a much larger spread across the wage distribution than for other employee categories. In addition, production workers experience positive wage growth higher up in the wage distribution than other employees. The overall result is, however, very clear, no matter what the employee category: employees who find themselves in 1997 in the lower part of their respective wage distribution experience substantially higher wage growth than those who are located in the upper part. 
The estimated effect of all of these determinants on the growth of total compensation are very similar, which is not surprising, given that the different bonus payments only account for a small share of total compensation.

\section{Wage Arrears}

Withholding wages on a regular basis has been the experience of many Russian workers during most of the nineties (see, e.g., Lehmann, Wadsworth and Acquisti, 1999, and Earle and Sabirianova, 2002), and is therefore an important component of a firm's wage policy. The personnel data of the firm records the stock of wage arrears for each employee on the $31^{\text {st }}$ of December of the respective year. According to this data, wage arrears were recorded only at the end of 1998. We do have, however, information about the monthly stocks of wage arrears by employee type taken from the CERT regional firm panel data. According to this data source, employees at the firm at hand were confronted with wage arrears in the years 1998 and 1999. Figure 9, which is based on the CERT data, shows that wage arrears start to accumulate in January 1998 and peak after roughly one year and then decline continuously until they dissipate at the end of 1999. This suggests that wage arrears were used by the firm to cushion the shock arising from the build-up to the financial crisis, its actual occurrence and its aftermath.

Real wage arrears as a fraction of monthly wages were lowest on average among production workers. Accountants were most adversely affected by arrears. Managers were not spared and also had part of their wages withheld. Compared to the general situation in Russia in 1998, the non-payment of wages in our firm was, however, not dramatic. Goskomstat reports total wage arrears in 1998 in Russia, which amount to roughly two monthly wages, while all average wage arrears in the 
firm never amounted to more than one tenth of a month of 1997 wages. Even the average accumulated wage arrears for the worst affected group, accountants, never exceeded a third of a month of 1997 wages. $^{20}$

Since wage arrears in the firm only started in 1998 and since they had disappeared by the end of 1999, we only have one cross section (the year 1998) of the stock of arrears of all employees. To the extent that the information derived from the CERT regional firm panel data that accumulated wage arrears peaked in December 1998 is valid, the wage arrears data based on the personnel data capture that moment when presumably their incidence, their level and their variation was largest across the population.

The personnel data show that roughly 60 percent of all employees had no arrears at all at the end of 1998 and only 10 percent experienced arrears worth one week of monthly pay or more. The summary statistics of Table 9 show how limited wage arrears are for the entire workforce and give some details of how these limited arrears are distributed across the five types of employees. Arrears are shown in thousands of 1997 Rubles (A) and as a fraction of 1997 monthly wages (B). The panel for all employees shows very small mean values and a relatively small spread no matter how arrears are measured. Even at the 90 percentile arrears never amount to more than a third of monthly wages and the maximum value is given by slightly more than one month of wages. What is clear from the table is that production workers had been treated favorably by the firm in 1998 , since even at the 75 percentile we do not observe any arrears. The other employee categories have a more even incidence since we find positive wage arrears already at the 25 percentile (not shown in the table).

\footnotetext{
${ }^{20}$ This is consistent with our interpretation of the crisis as primarily a short-time liquidity crisis for the firm, followed by a medium-term improvement in economic performance driven by the devaluation of the ruble and the consequent improved competitiveness of the firm.
} 
However, the worst treatment seems to have been reserved for accountants, who have the highest levels of wage arrears throughout the distribution.

How are wage arrears correlated with real wages? To answer this question we perform simple Tobit regressions, where those observations with zero wage arrears are left-censored and where real arrears and arrears in terms of wages are regressed on real wages. An extended model includes dummies for the employee types. The bivariate model implies that employees with higher wages have lower levels of wage arrears (column (2) of Table 10); however, once we include controls for employee type there is a positive correlation between real wages and real wage arrears (column 3). Larger wages, on the other hand, imply smaller wage arrears in terms of monthly wages whether we control for employee type or not (columns (4) and (5)). The coefficients on the dummies in columns 3 and 5 also confirm that, controlling for wages, production workers were best treated while accountants had a particularly bad experience regarding wage arrears.

To see whether the incidence of wage arrears varies across certain characteristics of employees we also perform simple probit regressions for the entire sample and for the different employee categories separately. The results, which are not shown here, ${ }^{21}$ show some robust partial correlations. Most noteworthy is the result that employees with longer tenure were less affected by wage arrears than those with average tenure. This result is particularly strong for engineering staff and production workers and seems to indicate that, at least in this firm long-tenured employees were given preferential treatment and thus highly valued. This outcome is in sharp contrast to studies that base their evidence on nation-wide surveys and that suggest that long tenure in the nineties in Russia was associated with a larger incidence of wage arrears

\footnotetext{
${ }^{21}$ They are available on request from the authors.
} 
resulting from poor labor market prospects for long-serving employees (Lehmann et al., 1999, and Earle and Sabirianova, 2002). It is, therefore, feasible that in our firm (where mass layoffs finished in 1993) long tenure implies having acquired a large stock of firm-specific human capital that is valuable to the firm even under the circumstances of a demand driven economy. A further robust result is the inverse relationship between educational attainment and the incidence of wage arrears, pointing to a better treatment of more educated employees. Female and male employees are equally treated as far as wage arrears are concerned if we look at the entire sample. This result is driven by the fact that male production workers experience smaller arrears than their female counterparts while among the engineering staff - the second largest group after production workers - females are less affected. The simple probit regressions make clear in any case that, within this firm, employees were not equally treated when it came to withholding wages and that top management tried to keep content those employees that it valued most.

\section{Inequality}

A comparison of the Figures 4 and 7 reveals that real wage distributions become more compressed. The difference in the median wage and wages for an employee at the $90^{\text {th }}$ percentile of the distribution is reduced by slightly less than 15 percentage points during the period from 1997 to 2002. The gap between the wage of an employee at the $10^{\text {th }}$ percentile of the wage distribution and the median wage narrowed by 37 percentage points from 1997 to 2002 . Hence, the fall in wage inequality comes about by relative wage gains of employees in the lower part of the wage distribution. Gini coefficients reported in column (1) of Table 11 corroborate the decline in inequality of wages and total compensation for the entire workforce. The Gini coefficients in columns (2) - (6) show that wage and compensation inequality falls also within all 
employee categories in the aftermath of the financial crisis. However, this process of wage and compensation compression is not monotonic for all employee categories. For example, inequality fell to very low levels for service staff and managers in 2001, but rises again thereafter.

The Gini coefficient can be written as $\mathrm{G}=(2 / \mu) \operatorname{cov}(\mathrm{y}, \mathrm{F}(\mathrm{y}))$, where $\mathrm{y}$ is income, $\mathrm{F}(\mathrm{y})$ is the distribution function of $\mathrm{y}$ and $\mu$ is mean income (see, e.g., Lambert, 2001). A simple algebraic manipulation then arrives at the decomposition of $\mathrm{G}$ into its components by income source:

$$
G=\sum_{k} R_{k} G_{k} S_{k}
$$

where $R_{k}$ is the rank correlation of income source $\mathrm{k}$ with the distribution of total income, $G_{k}$ is the Gini of income source k and $S_{k}$ is the share of component k in total income. $^{22}$ The decomposition of the Gini coefficient by income source is particularly interesting in our context to establish the contribution of the various components to inequality. The k-th component of equation (1) divided by G, i.e., $\frac{R_{k} G_{k} S_{k}}{G}$, gives us the share of income source k in total inequality. Dividing this expression by $S_{k}$ shows the inequality component as a fraction of its income share. Finally, $\frac{R_{k} G_{k} S_{k}}{G}-S_{k}$ approximates the impact of a 1 percent change of income source $\mathrm{k}$ on overall inequality. This latter measure can also be understood as income source k's marginal effect relative to the overall Gini (see Lerman and Yitzaki, 1985).

The upper panel of Table 12 presents the Gini coefficients for the different compensation components. Inequality in wages and in the extra bonus gradually falls

\footnotetext{
${ }^{22}$ This decomposition is due to Lerman and Yitzaki (1985) who show that $G=(2 / \mu) \sum_{k=1}^{K} \operatorname{cov}\left(y_{k}, F\right)=\sum_{k=1}^{K}\left[\operatorname{cov}\left(y_{k}, F\right) / \operatorname{cov}\left(y_{k}, F_{k}\right)\right]\left[2 \operatorname{cov}\left(y_{k}, F_{k}\right) / \mu_{k}\right]\left[\mu_{k} / \mu\right]$.
} 
with the exception that inequality in the extra bonus was zero in the crisis year 1998 since no extra bonus was paid at all. The other two bonus types show a more erratic behavior. The compression in total compensation is less pronounced than the compression in wages, not least because the Gini coefficients of bonuses were far higher than the Gini coefficients of wages (see top panel of Table 12). Despite this large difference between the Gini coefficients of bonus payments and the Gini coefficient of wages, bonuses contributed little to overall inequality for two reasons. First, their shares were small relative to the share of wages (see Table 5). Second, the rank correlations of all bonus payments with the distribution of total income were far weaker than the nearly perfect rank correlation of wages (see bottom panel of Table 12$).{ }^{23}$ Wages contributed slightly less to overall inequality than their share in total income, as Table 13 demonstrates, and therefore have had an (hypothetical) attenuating impact on overall inequality in all years as the bottom panel of Table 13 reveals. Monthly bonus payments, in contrast, "aggravated" overall inequality in all years apart from 1999.

Alternative measures of inequality like general entropy indices confirm the findings concerning the compression of wages and total compensation. The general entropy index, which is given by

$$
G E I(\alpha)=\left[\frac{1}{N \alpha(\alpha-1)}\right] \sum_{i}\left[\left(\frac{x_{i}}{\mu}\right)^{\alpha}-1\right]
$$

where $\mathrm{N}$ is the number of observational units, $\mathrm{x}_{\mathrm{i}}$ is the level of earnings of the $\mathrm{i}$-th observational unit, and $\mu$ is mean earnings, allows us to assess whether the change in inequality is mostly driven by changes at the bottom or by changes at the top of the

\footnotetext{
${ }^{23}$ One might find it puzzling that the Gini of total compensation is very close to the Gini of wages given these far higher Gini coefficients for bonus payments. For example in 1997 the Gini of total compensation amounts to 0.2928 while the Gini of wages is 0.2802 . A simple back of the envelope calculation, using equation (1), brings home the point that the large $G_{k}$ 's of the bonus components are "wiped out" by their small $S_{k}$ 's and $R_{k}$ 's.
} 
distribution, by varying the parameter $\alpha$. The index is more sensitive to changes at the top of the distribution the larger is $\alpha .{ }^{24}$ Since the fall in the general entropy index for a parameter value of -1 is more pronounced than for a value of 1 , we conclude that the relative gains at the bottom of the wage and the compensation distributions are the more important driving factors of the fall in overall inequality. If we give more weight to wages in the lower part of the distribution, our measure of overall wage inequality, GEI(-1) indicates that inequality fell by 62 percent between 1997 and 2002. If, on the other hand, the index is more sensitive to wages in the upper part of the distribution then measured overall wage inequality fell by "only" 44 percent (see columns (1) and (4) of panel a of Table 14). Falling inequality is mostly driven by compression within the lower part of the wage distribution in all employee categories except for managers. $^{25}$

The general entropy index can also be additively decomposed into the within and between parts of inequality. This decomposition reveals that inequality within employee categories dominate overall wage inequality in 1997, while in 2002 within and between group inequality are of roughly equal magnitude (see columns (2) and (3) as well as columns (5) and (6) of top panel of Table 14). The GEI(-1) and GEI(1) measures indicate that within-inequality fell, respectively, by 69 and 60 percent and that between-inequality was reduced by 37 and 1 percent respectively. Most of the compression in the overall wage distribution between 1997 and 2002 occurred because there was tremendous compression of wages within employee categories.

\footnotetext{
${ }^{24} \mathrm{GEI}(\alpha)$ encompasses several well known inequality measures: for example, GEI( 0$)$ corresponds to the mean log deviation, GEI(1) to the Theil index and GEI(2) to one half of the square of the coefficient of variation. We use a modified version of the Stata module "descogini" by Alejandro Lopez-Feldman for our calculations. See Feldman (2005).

${ }^{25}$ For example, wage inequality for service staff and production workers fell by 70 percent and 58 percent if we take GEI(-1), but only by 60 percent and 41 percent respectively if we use GEI(1) to calculate percentage changes in inequality. For managers, on the other hand, these percentage changes amount to 64 and 68 percent. Detailed results are available from the authors upon request.
} 
These patterns also hold for inequality of total compensation as the statistics in the bottom panel of Table 14 demonstrate.

\section{Conclusions}

Having a rich personnel data set of one Russian firm for the years 1997 to 2002 at our disposal, we can trace out the evolution of wages, total compensation and employment in a period that included the financial crisis of 1998. The observed evolution points to "price" rather than "quantity" adjustment within the firm during the crisis as employment remained stable but real wages and real compensation fell substantially. Our evidence thus shows that the firm does not refrain from substantially cutting real wages, taking advantage of a high-inflationary environment.

The downward adjustment of earnings leads to persistent welfare losses among employees since real wages and real compensation levels had not recovered to pre-crisis levels by 2002, even though the firm's financial situation was then better than before the crisis. The firm, which was a high-wage firm prior to 1998, makes use of the high inflation that manifests during and in the aftermath of the financial crisis in order to extract rents from employees. These welfare losses were, however, not spread evenly across all employees, since the firm curbs earnings most for those who earned the highest rents, which results in a tremendous compression of real wages. Wage growth regressions spanning the years 1997 to 2002 show disproportionate wage growth for those employees located in the lowest four deciles of the wage distribution in 1997 while employees positioned in the highest four deciles are confronted with relative wage losses. Relative to production workers, service staff and engineers have wage gains over the period, while accountants and managers have small wage losses. 
The firm was in a position to extract rents from its employees because of a fall in outside opportunities in the local labor market as evidenced by dramatically falling separation rates after 1999. At the bottom end of the firm's wage distribution there are, however, few rents before the crisis and the firm seems to pay the opportunity cost for employees at that end of the distribution throughout the reported period.

Wage arrears occur in this firm in 1998 and 1999, but they are a minor issue as the average level of arrears never amounted to more than one tenth of a month of 1997 monthly wages. Our findings also indicate that production workers as well as employees with long tenure face fewer wage arrears. The worst affected group are accountants who seem further penalized by lower nominal wage growth than other employee categories. It is possible that this treatment by the firm was a reaction to a rather loose firm attachment of accountants which is demonstrated through their higher turnover rates than those of other employee groups.

Our analysis thus shows that the costs of the crisis are unevenly distributed across the firm's workforce and that the firm tries to shelter those workers whom it values most from the fallout of the crisis. All in all, though, we take the differential treatment of employee groups within the firm as evidence that market forces strongly influence the wage policies of our firm.

Since our firm is in manufacturing, the empirical analysis of wages and employment gives us insights that can possibly be generalized to workers in the tradable sector of any developing country undergoing a macroeconomic shock. ${ }^{26}$

\footnotetext{
${ }^{26}$ Fallon and Lucas (2002) assess the impact of financial crises on labor markets and household income and record the different experiences of workers in the traded and non-traded sector during a financial crisis and its aftermath in their sample of developing countries. In these countries agriculture is the main traded sector, while in Russia manufacturing belongs to this sector. In an interview, the CEO of the analyzed Russian firm clearly states that the prospects of the firm are strongly determined by movements in the real exchange rate since the firm competes with importers from the $\mathrm{EU}$ in the Russian and other markets of the CIS.
} 


\section{References}

Altonji, Joseph G. and Paul J. Devereux (2000), “The Extent and Consequences of Downward Nominal Wage Rigidity," in Solomon W. Polachek (ed.), Research in Labor Economics, 19, 383-431.

Baker, George, Michael Gibbs and Bengt Holmstrom (1994), "The Wage Policy of a Firm," Quarterly Journal of Economics, 109(4), 921-955.

Bauer, Thomas, Holger Bonin and Uwe Sunde (2003), "Real and Nominal Wage Rigidities and the Rate of Inflation: Evidence from West German Micro Data," IZA Discussion Paper No. 959.

Bewley, Truman F. (1999), Why Wages Don't Fall During a Recession, Harvard University Press.

Boeri, Tito and Katherine Terrell (2002), "Institutional determinants of labor reallocation in transition", Journal of Economic Perspectives, 16(1), 51-76.

Card, David and David Hyslop (1997), "Does Inflation Grease the Wheels of the Labor Market?," in Romer, C. and D. Romer (eds.), Reducing Inflation: Motivation and Strategy, pp. 71-113. Chicago University Press.

Chiodo, Abigail J. and Michael T. Owyang, (2002), "A Case Study of a Currency Crisis: The Russian Default of 1998." In The Federal Reserve Bank of St. Louis Review, November/December.

Commander, Simon, McHale, John, and Yemtsov, Ruslan (1995), "Unemployment, Restructuring, and the Labor Market in Eastern Europe and Russia: Russia." In Simon Commander and Fabrizio Coricelli, Eds., Unemployment, Restructuring, and the Labor Market in Eastern Europe and Russia, pp. 147191. Washington, DC: EDI/World Bank, 1995.

Dohmen, Thomas J. (2004), Performance, Seniority, and Wages: Formal Salary Systems and Individual Earnings Profiles, Labour Economics, 11(6), 741-763.

Dohmen, Thomas J. and Gerard A. Pfann (2004), "Worker Separations in a Nonstationary Corporate Environment," European Economic Review, 2004, vol. 48(3), 645-663.

Earle, John S. and Klara Sabirianova (2002), "How Late to Pay? Understanding Wage Arrears in Russia”, Journal of Labor Economics, 20(3), 661-707. 
Eder, M., Yakovlev, A. and A. Çarkoglu, (2003), "The suitcase trade between Turkey and Russia: microeconomics and institutional structure", Working Paper WP4/2003/07, Higher School of Economics, Moscow.

Fallon, Peter R. and Lucas, Robert E.B. (2002), “The Impact of Financial Crises on Labor Markets, Household Incomes and Poverty." The World Bank Research Observer, 17(1), pp. 21-45.

Fehr, Ernst and Lorenz Goette (2005) "Robustness and Real Consequences of Downward Nominal Wage Rigidity”, Journal of Monetary Economics 52, 779 - 804.

Gibbons, Robert and Michael Waldman (1999), "Careers in Organizations: Theory and Evidence", in Orley C. Ashenfelter and David Card (eds.), Handbook of Economics, Vol. 3b, 2373-2437, Elsevier Science, Amsterdam.

Kharas, Homi, Brian Pinto and Sergei Ulatov (2001), “An Analysis of Russia’s 1998 Meltdown: Fundamentals and Market Signals." Brookings Papers on Economic Activity, 1, 1-67.

Lambert, Peter, J. (2001), The Distribution and Redistribution of Income, Manchester University Press, Manchester and New York.

Lazear, Edward P. and Paul Oyer (2004), "Internal and External Labor Markets: A Personnel Economics Approach”, Labour Economics, 11(5), 527-554.

Lazear, Edward P. (1999), "Personnel Economics: Past Lessons and Future Directions" Presidential Address to the Society of Labor Economists, San Francisco, May 1, 1998, Journal of Labor Economics, 17(2), 199-236.

Lehmann, Hartmut, Jonathan Wadsworth and Alessandro Acquisti (1999), "Grime and Punishment: Job Insecurity and Wage Arrears in the Russian Federation." Journal of Comparative Economics, 1999, 27(4), 595-617.

Lerman, Robert I. and Shlomo Yitzaki (1985), "Income Inequality Effects by Income Source: A New Approach and Applications to the United States." In The Review of Economics and Statistics, 67 (1), 151-156.

Lopez-Feldman, Alejandro (2005), "DESCOGINI: Stata module to perform Gini decomposition by income source". http://ideas.repec.org/c/boc/bocode/s456001.html 
Summers, Lawrence H. and John Williamson (2001), [“An Analysis of Russia’s 1998 Meltdown: Fundamentals and Market Signals."] Comments and Discussion. In Brookings Papers on Economic Activity, vol. 1, 51-67.

Wilson, Beth Ann (1996), "Movement of Wages over the Business Cycle: an IntraFirm View," Board of Governors of the Federal Reserve System (U.S.), Finance and Economics Discussion Paper Series, 1997-1.

Wilson, Beth Ann (1999), Wage Rigidity: A Look Inside the Firm, Board of Governors of the Federal Reserve System, Finance and Economics Discussion Series. 


\section{FIGURES}

Figure 1

Profitability (profit/sales in \%)

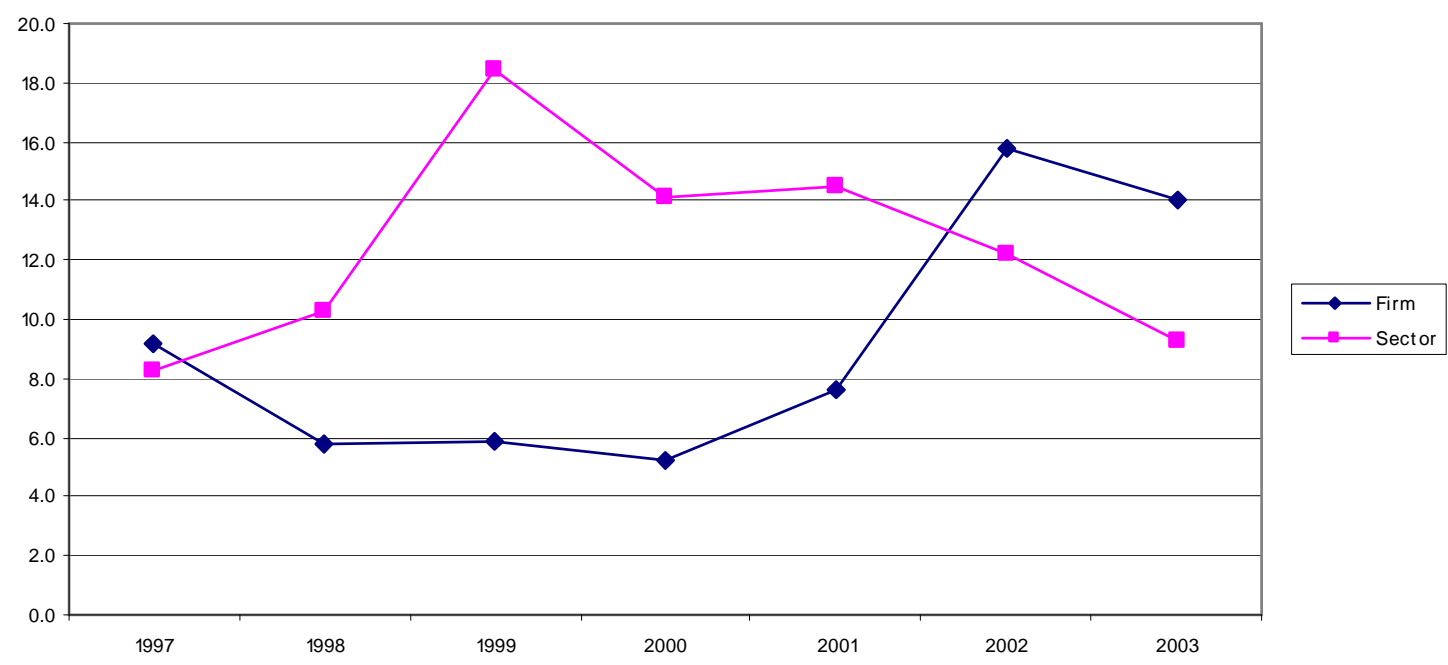

Figure 2

Real Monthly Wage in Thousand 1997 Rubles

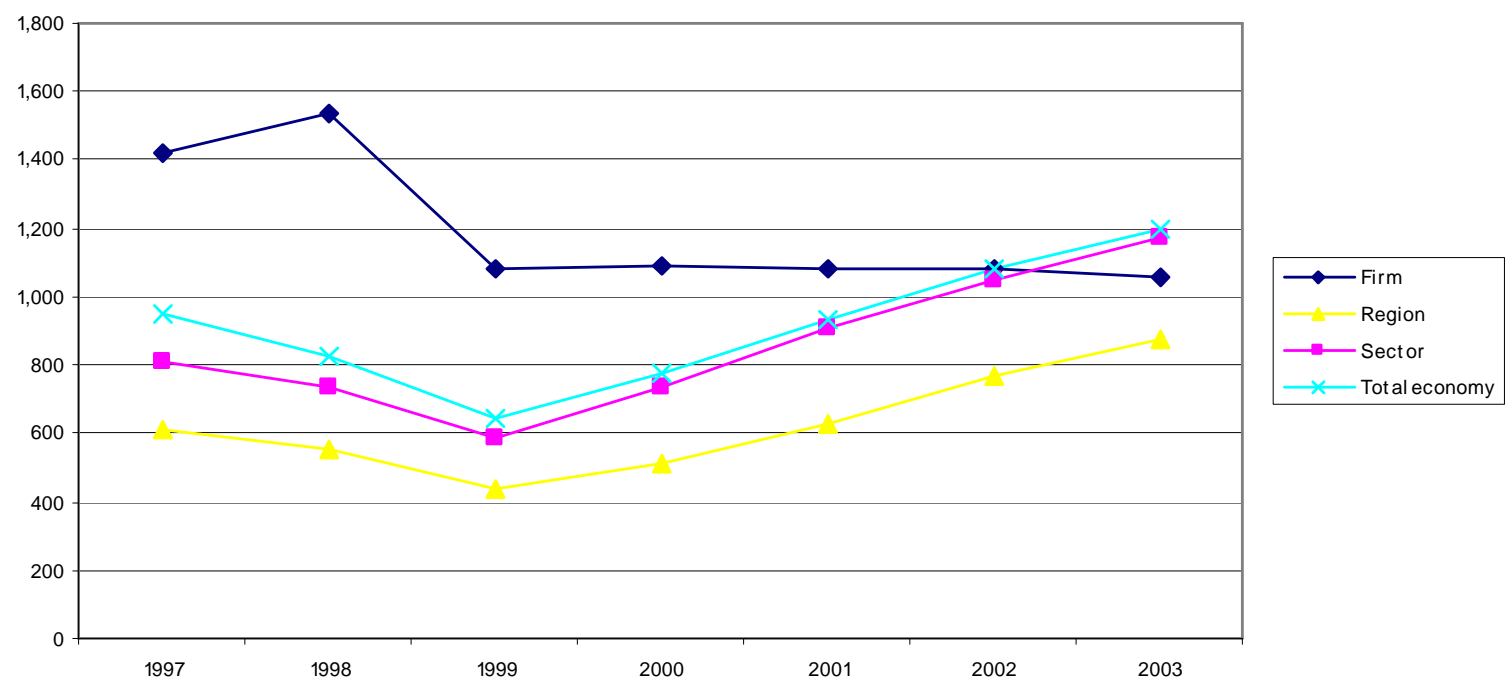


Figure 3

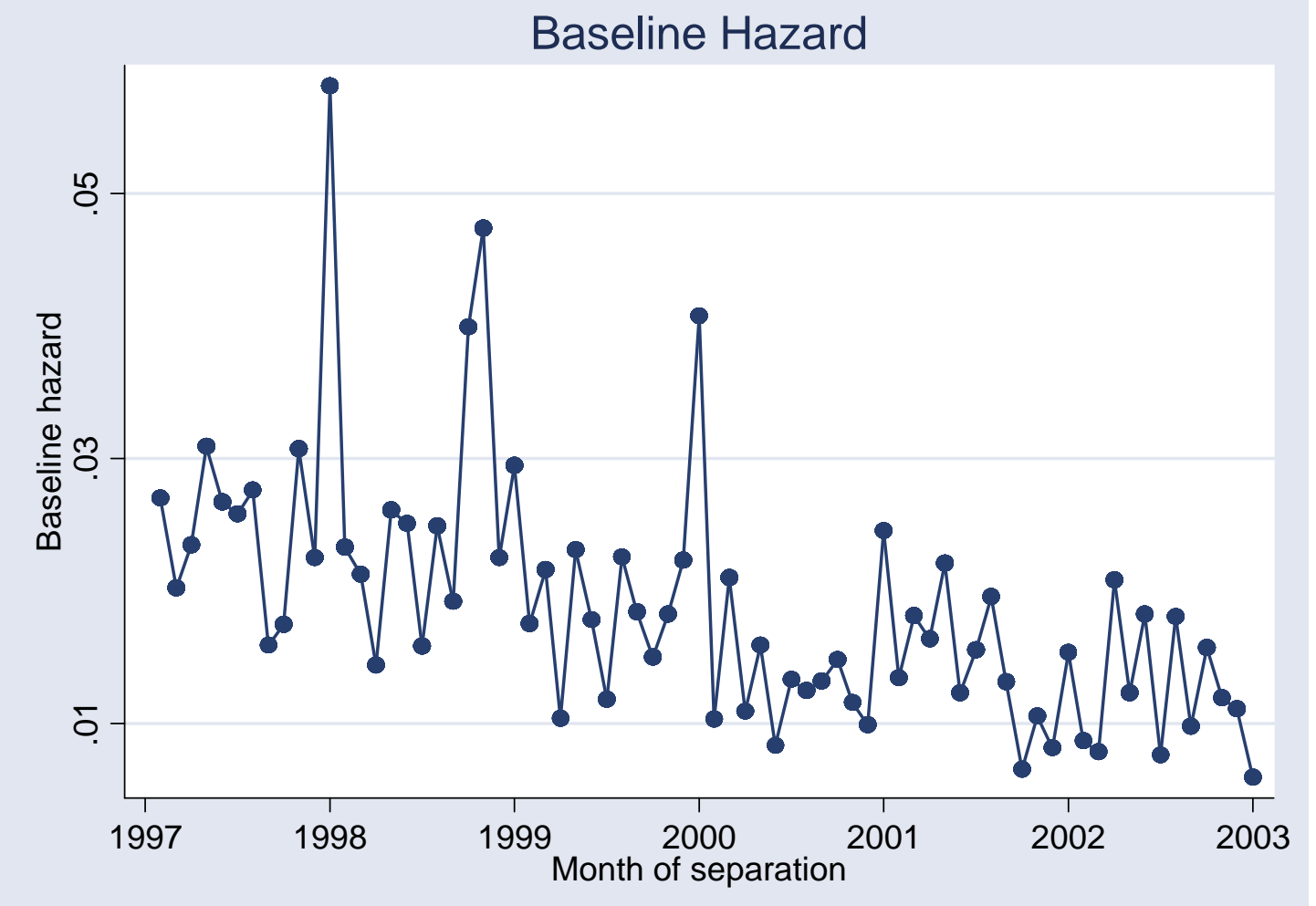


Figure 4

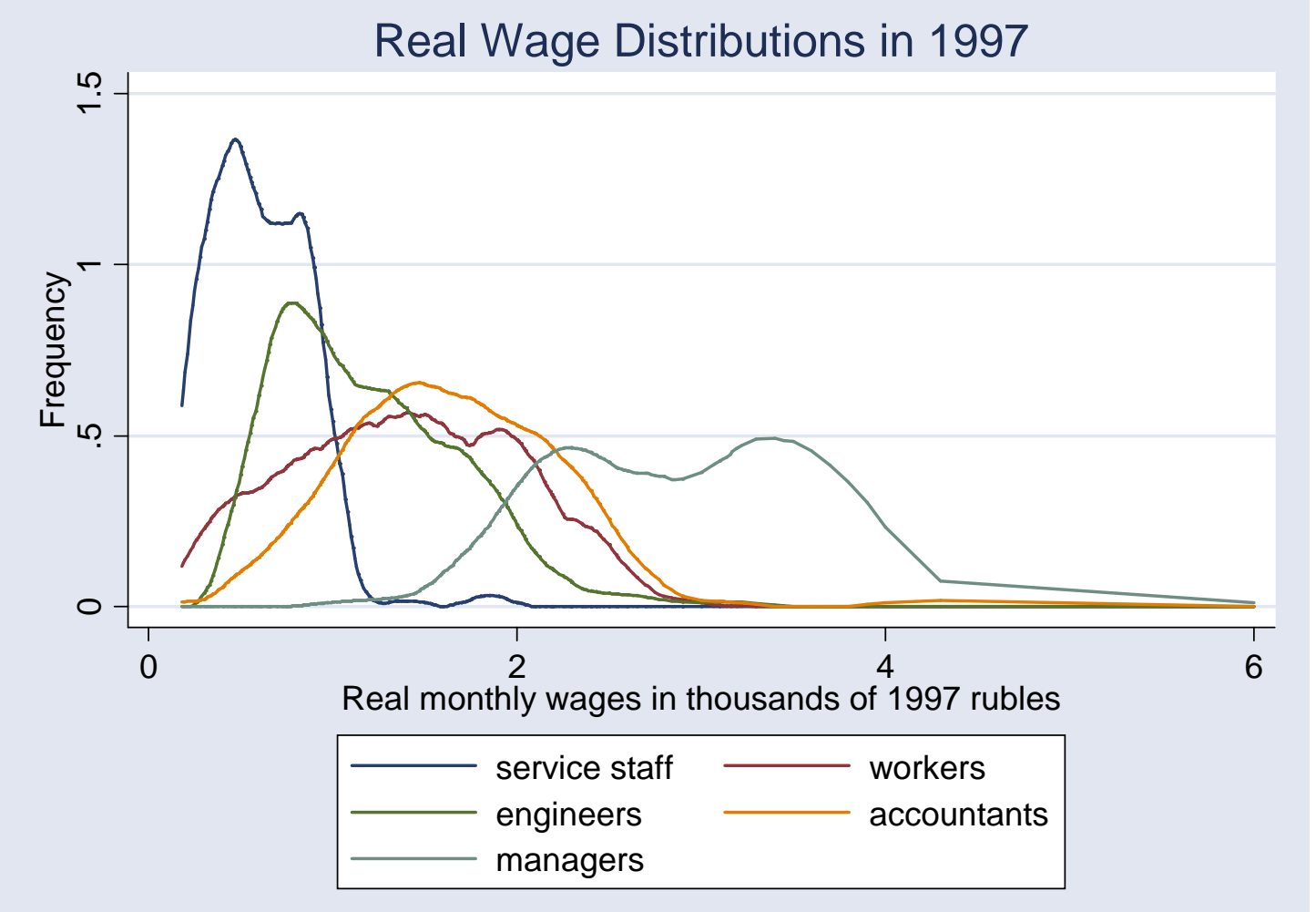

Figure 5 Distribution of basic real wage in rubles - all employees

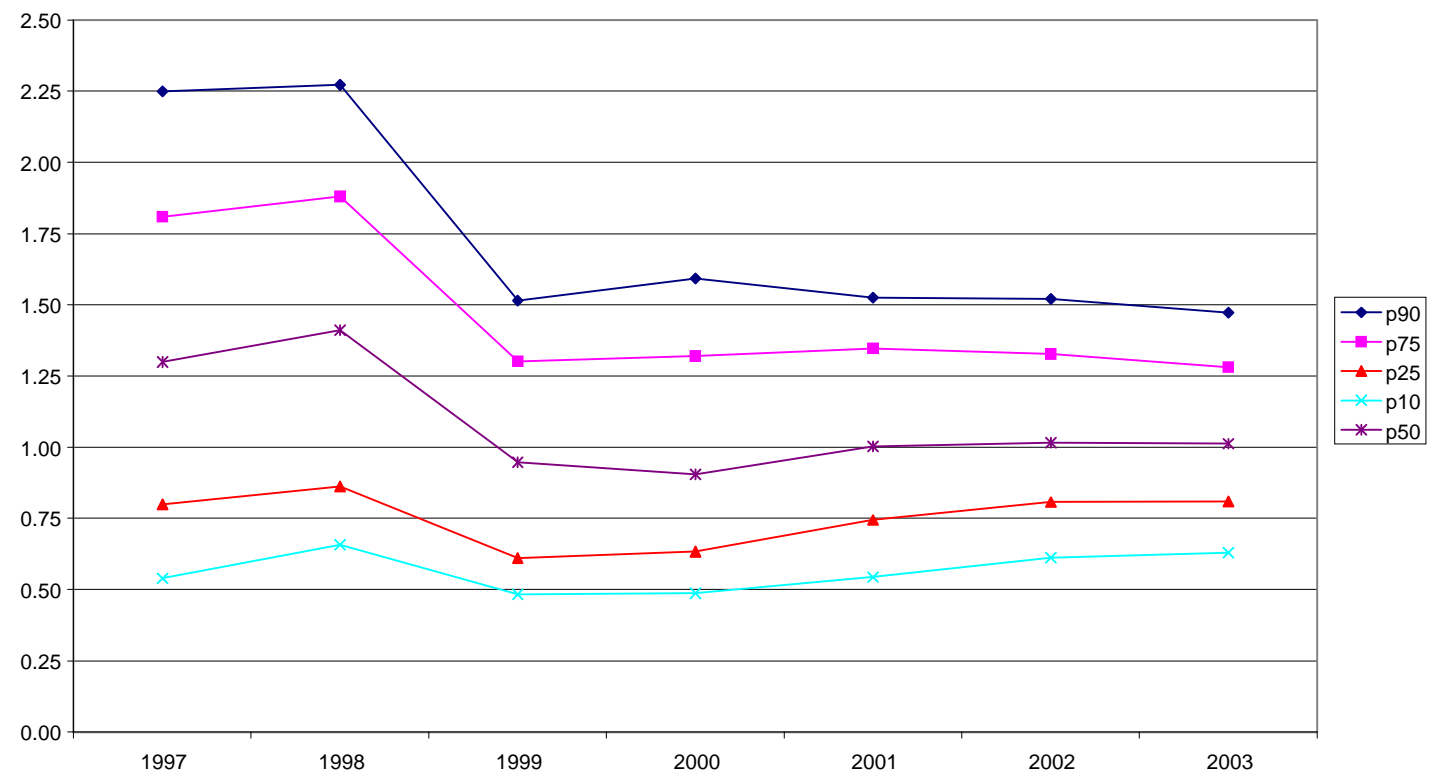


Figure 6 Distribution of total real compensation in rubles - all employees

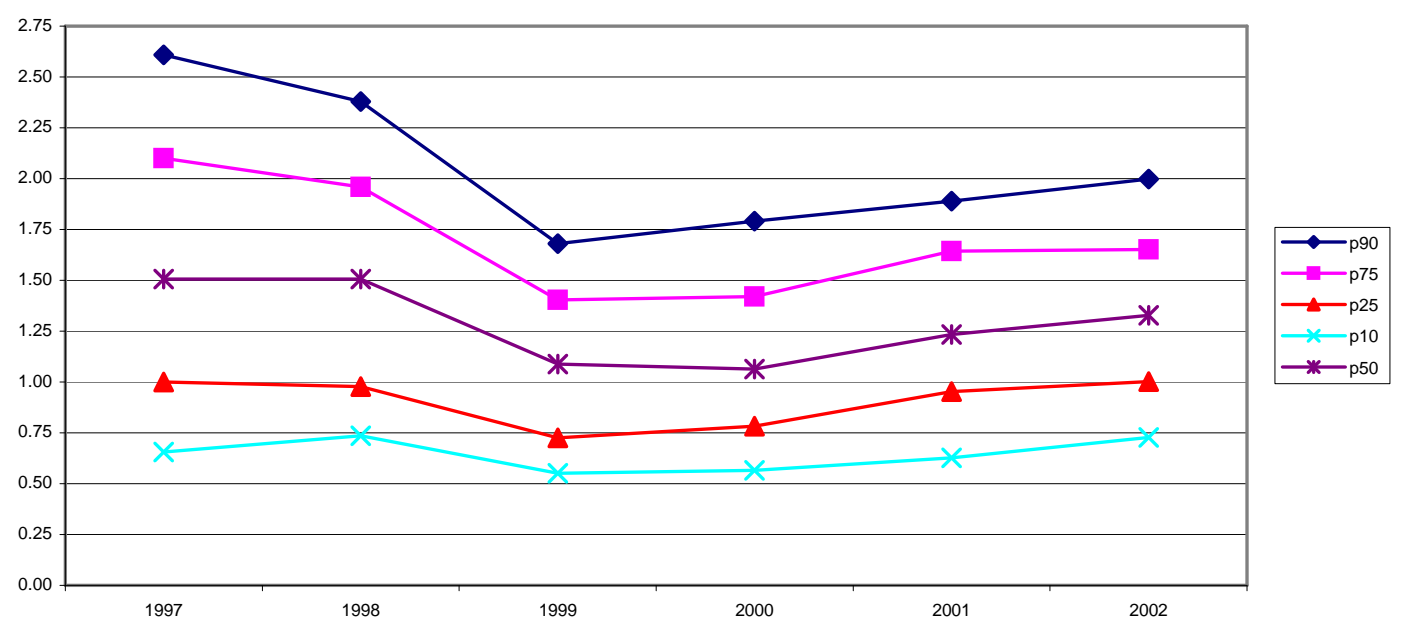


Figure 7

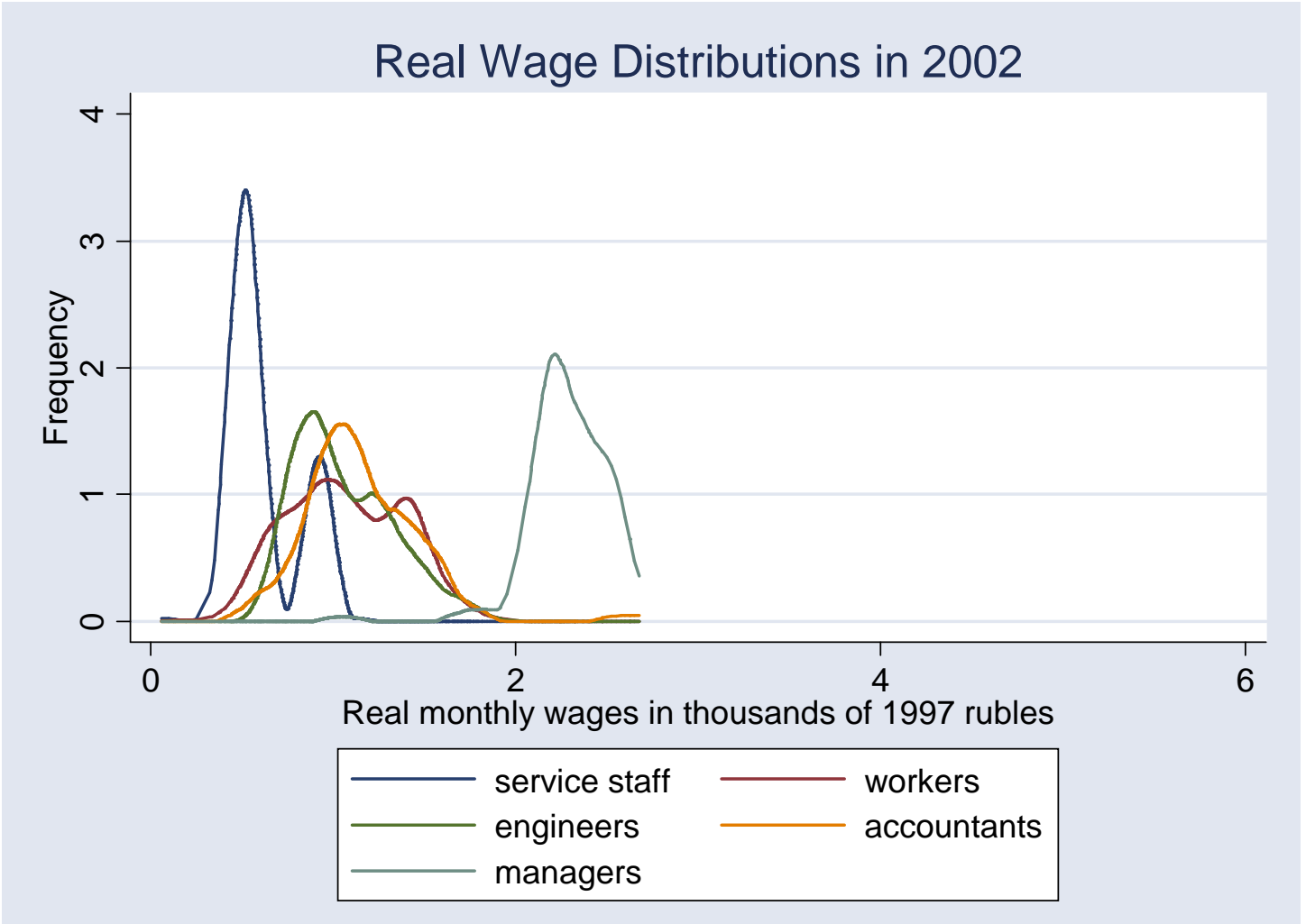




\section{Figure 8}

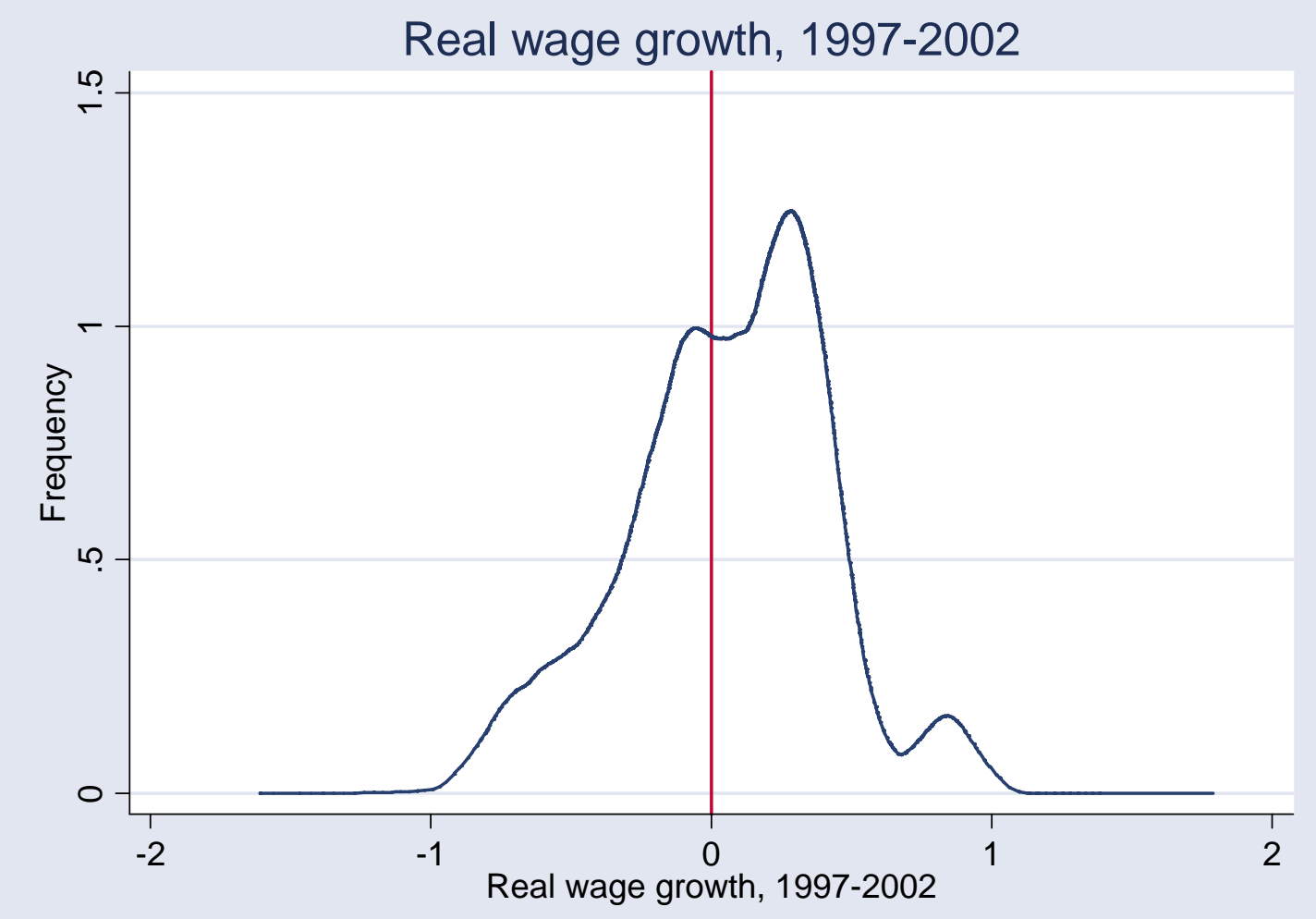

Figure 9 Real Arrears in Months of 1997 Wages

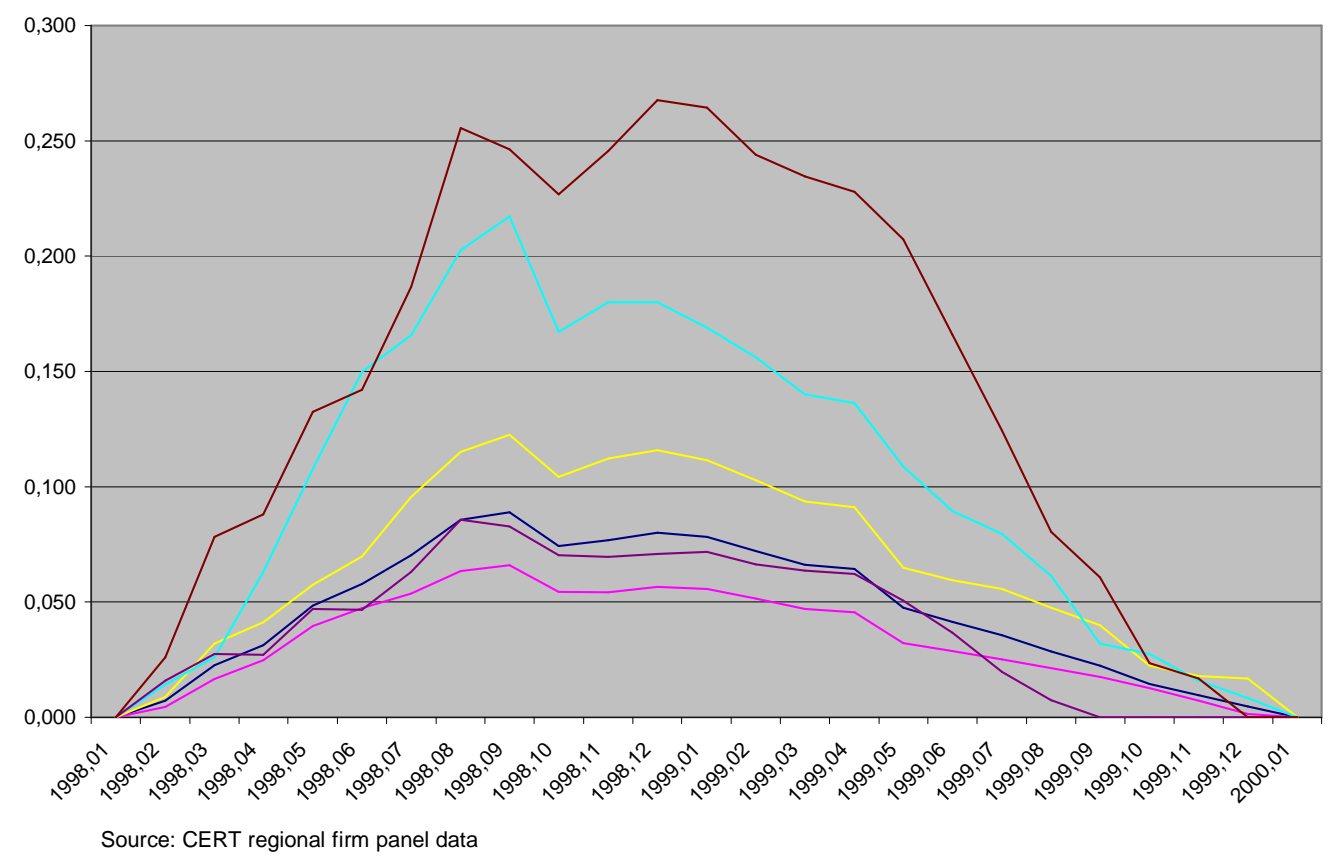


TABLES

Table 1: Composition of Workforce (in \%), 1997 to 2002

\begin{tabular}{cccccccc} 
Year & $\begin{array}{c}\text { Service } \\
\text { staff }\end{array}$ & Engineers & $\begin{array}{c}\text { Production } \\
\text { workers }\end{array}$ & Accountants & Managers & Total & $\begin{array}{c}\text { Absolute } \\
\text { number of } \\
\text { employees }\end{array}$ \\
\hline 1997 & 7.1 & 24.8 & 62.1 & 2.2 & 3.8 & 100 & 3032 \\
1998 & 7.0 & 24.4 & 62.6 & 2.1 & 3.8 & 100 & 3081 \\
1999 & 6.9 & 24.6 & 62.6 & 2.1 & 3.8 & 100 & 3077 \\
2000 & 7.0 & 24.4 & 62.8 & 2.1 & 3.8 & 100 & 3110 \\
2001 & 6.9 & 24.0 & 63.2 & 2.0 & 3.8 & 100 & 3175 \\
2002 & 6.9 & 23.7 & 63.6 & 1.9 & 3.8 & 100 & 3221 \\
\hline \hline
\end{tabular}


Table 2: Hiring and Separation Rates (in \%), 1997-2002

\begin{tabular}{|c|c|c|c|c|c|c|c|c|c|c|c|c|c|c|c|c|c|c|}
\hline \multirow[b]{2}{*}{ Year } & \multicolumn{3}{|c|}{ Service staff } & \multicolumn{3}{|c|}{ Engineers } & \multicolumn{3}{|c|}{$\begin{array}{c}\text { Production } \\
\text { workers }\end{array}$} & \multicolumn{3}{|c|}{ Accountants } & \multicolumn{3}{|c|}{ Managers } & \multicolumn{3}{|c|}{ All Employment } \\
\hline & In & Out & Total & In & Out & Total & In & Out & Total & In & Out & Total & In & Out & Total & In & Out & Total \\
\hline 1997 & 13.7 & 14.2 & 27.8 & 7.8 & 7.8 & 15.5 & 16.4 & 15.2 & 31.5 & 19.1 & 23.5 & 42.6 & 10.8 & 9.9 & 20.7 & 13.9 & 13.2 & 27.1 \\
\hline 1998 & 13.3 & 13.3 & 26.5 & 6.3 & 5.8 & 12.1 & 18.0 & 16.1 & 34.1 & 20.0 & 23.1 & 43.1 & 16.1 & 13.4 & 29.5 & 14.7 & 13.5 & 28.2 \\
\hline 1999 & 7.6 & 5.7 & 13.3 & 5.3 & 4.9 & 10.3 & 11.8 & 11.8 & 23.7 & 11.1 & 14.3 & 25.4 & 4.3 & 4.3 & 8.7 & 9.6 & 9.5 & 19.1 \\
\hline 2001 & 7.8 & 6.8 & 14.6 & 5.7 & 5.1 & 10.8 & 11.5 & 7.4 & 19.0 & 13.6 & 19.7 & 33.3 & 5.0 & 1.7 & 6.7 & 9.6 & 6.5 & 16.2 \\
\hline 2002 & 5.4 & 3.6 & 9.0 & 2.9 & 3.0 & 5.9 & 8.7 & 7.8 & 16.5 & 8.1 & 9.7 & 17.7 & 0.0 & 0.0 & 0.0 & 6.7 & 6.1 & 12.8 \\
\hline
\end{tabular}




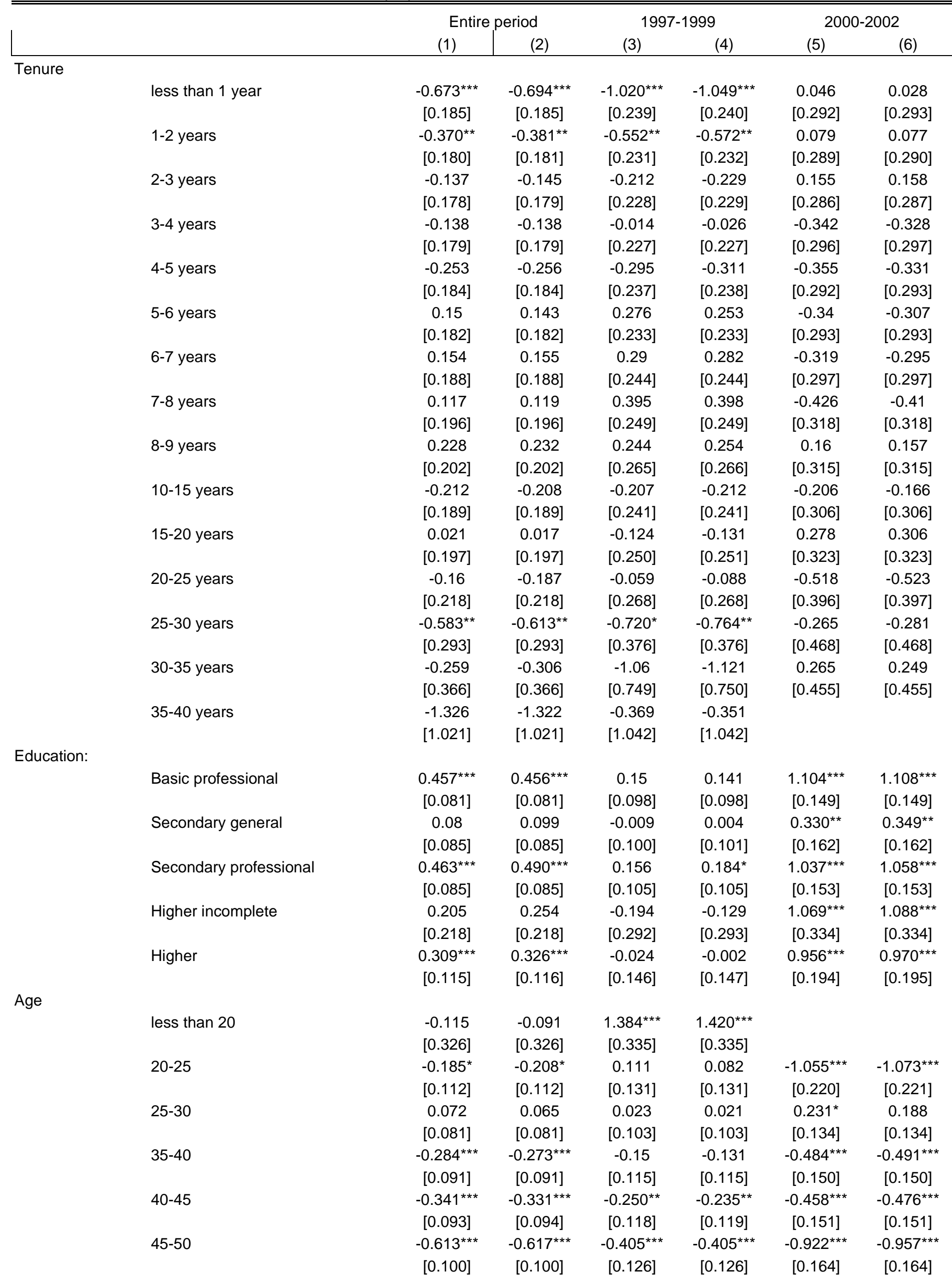




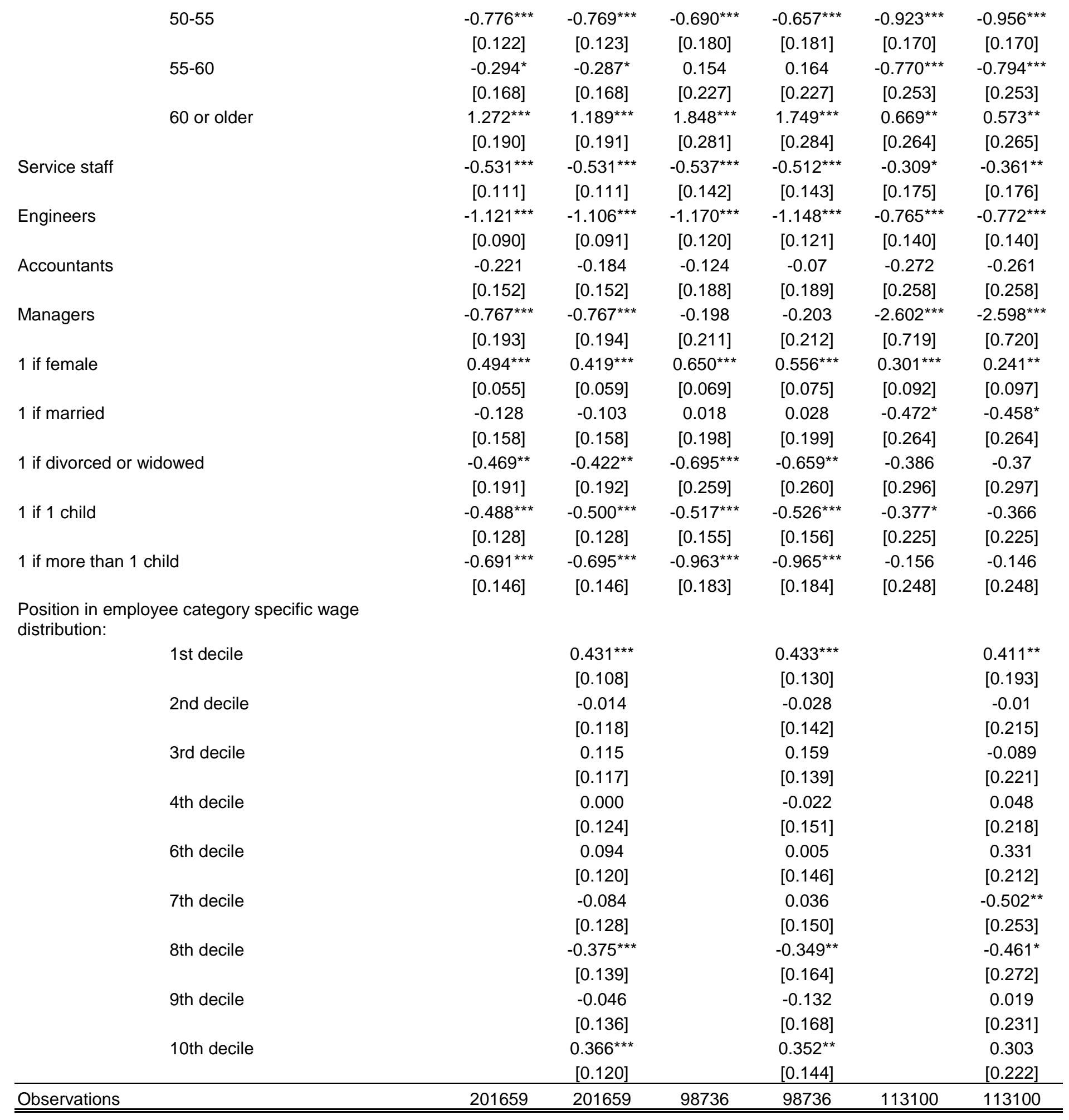

Standard errors in brackets

${ }^{*}$ significant at $10 \%$; ${ }^{* *}$ significant at $5 \%$; ${ }^{* *}$ significant at $1 \%$ 


\begin{tabular}{|c|c|c|c|c|c|c|}
\hline & \multicolumn{6}{|c|}{ Dependent Variable: log(real wage) in 1997} \\
\hline & $\begin{array}{c}\text { All employees } \\
\text { (1) }\end{array}$ & $\begin{array}{c}\text { Service } \\
\text { staff } \\
(2)\end{array}$ & $\begin{array}{c}\text { Engineers } \\
\text { (3) }\end{array}$ & $\begin{array}{c}\text { Production } \\
\text { workers } \\
\text { (4) }\end{array}$ & $\begin{array}{c}\text { Accountants } \\
\text { (5) }\end{array}$ & $\begin{array}{c}\text { Managers } \\
(6)\end{array}$ \\
\hline Tenure in years & $\begin{array}{l}0.028^{* * *} \\
{[0.007]}\end{array}$ & $\begin{array}{c}0.020 \\
{[0.028]}\end{array}$ & $\begin{array}{l}0.026^{*} \\
{[0.014]}\end{array}$ & $\begin{array}{l}0.030^{* * *} \\
{[0.010]}\end{array}$ & $\begin{array}{c}0.027 \\
{[0.041]}\end{array}$ & $\begin{array}{c}0.007 \\
{[0.026]}\end{array}$ \\
\hline Tenure squared/100 in years & $\begin{array}{l}-0.136^{* *} \\
{[0.067]}\end{array}$ & $\begin{array}{l}-0.269 \\
{[0.251]}\end{array}$ & $\begin{array}{l}-0.188 \\
{[0.134]}\end{array}$ & $\begin{array}{l}-0.119 \\
{[0.089]}\end{array}$ & $\begin{array}{l}-0.471 \\
{[0.481]}\end{array}$ & $\begin{array}{c}0.021 \\
{[0.237]}\end{array}$ \\
\hline Tenure cube /1000 in years & $\begin{array}{c}0.025 \\
{[0.016]}\end{array}$ & $\begin{array}{c}0.083 \\
{[0.055]}\end{array}$ & $\begin{array}{c}0.04 \\
{[0.033]}\end{array}$ & $\begin{array}{c}0.014 \\
{[0.021]}\end{array}$ & $\begin{array}{c}0.171 \\
{[0.152]}\end{array}$ & $\begin{array}{c}-0.007 \\
{[0.058]}\end{array}$ \\
\hline Age in years & $\begin{array}{c}0.034 \\
{[0.038]}\end{array}$ & $\begin{array}{c}0.013 \\
{[0.176]}\end{array}$ & $\begin{array}{c}0.012 \\
{[0.074]}\end{array}$ & $\begin{array}{l}-0.005 \\
{[0.049]}\end{array}$ & $\begin{array}{l}-0.479 \\
{[0.290]}\end{array}$ & $\begin{array}{l}-0.588 \\
{[0.424]}\end{array}$ \\
\hline Age squared/100 in years & $\begin{array}{l}-0.033 \\
{[0.103]}\end{array}$ & $\begin{array}{l}-0.009 \\
{[0.469]}\end{array}$ & $\begin{array}{l}-0.001 \\
{[0.198]}\end{array}$ & $\begin{array}{c}0.08 \\
{[0.133]}\end{array}$ & $\begin{array}{l}1.579^{*} \\
{[0.819]}\end{array}$ & $\begin{array}{c}1.541 \\
{[1.059]}\end{array}$ \\
\hline Age cube /1000 in years & $\begin{array}{l}-0.001 \\
{[0.009]}\end{array}$ & $\begin{array}{l}-0.001 \\
{[0.041]}\end{array}$ & $\begin{array}{l}-0.002 \\
{[0.017]}\end{array}$ & $\begin{array}{c}-0.01 \\
{[0.012]}\end{array}$ & $\begin{array}{l}-0.162^{* *} \\
{[0.075]}\end{array}$ & $\begin{array}{l}-0.131 \\
{[0.087]}\end{array}$ \\
\hline Basic professional & $\begin{array}{c}0.037 \\
{[0.029]}\end{array}$ & $\begin{array}{c}0.014 \\
{[0.087]}\end{array}$ & & $\begin{array}{c}0.036 \\
{[0.033]}\end{array}$ & & \\
\hline Secondary general & $\begin{array}{c}0.079^{* \star *} \\
{[0.028]}\end{array}$ & $\begin{array}{l}-0.027 \\
{[0.089]}\end{array}$ & & $\begin{array}{l}0.076^{* *} \\
{[0.032]}\end{array}$ & & \\
\hline Secondary professional & $\begin{array}{c}0.097^{* \star *} \\
{[0.030]}\end{array}$ & $\begin{array}{c}0.028 \\
{[0.104]}\end{array}$ & $\begin{array}{l}-0.123 \\
{[0.277]}\end{array}$ & $\begin{array}{c}0.100^{* * *} \\
{[0.036]}\end{array}$ & $\begin{array}{c}0.615 \\
{[0.390]}\end{array}$ & \\
\hline Higher incomplete & $\begin{array}{l}0.164^{\star \star} \\
{[0.069]}\end{array}$ & $\begin{array}{l}-0.088 \\
{[0.469]}\end{array}$ & $\begin{array}{l}-0.065 \\
{[0.284]}\end{array}$ & $\begin{array}{c}0.180 \\
{[0.114]}\end{array}$ & $\begin{array}{l}1.406^{\star *} \\
{[0.559]}\end{array}$ & $\begin{array}{c}0.035 \\
{[0.167]}\end{array}$ \\
\hline Higher & $\begin{array}{l}0.122^{* * *} \\
{[0.038]}\end{array}$ & $\begin{array}{c}0.187 \\
{[0.273]}\end{array}$ & $\begin{array}{l}-0.073 \\
{[0.277]}\end{array}$ & $\begin{array}{c}0.110 \\
{[0.069]}\end{array}$ & $\begin{array}{l}0.977^{* *} \\
{[0.396]}\end{array}$ & $\begin{array}{l}-0.042 \\
{[0.053]}\end{array}$ \\
\hline 1 if female & $\begin{array}{c}-0.319^{* * *} \\
{[0.019]}\end{array}$ & $\begin{array}{c}-0.236^{\star * *} \\
{[0.071]}\end{array}$ & $\begin{array}{c}-0.155^{\star \star *} \\
{[0.030]}\end{array}$ & $\begin{array}{c}-0.428^{\star * *} \\
{[0.027]}\end{array}$ & $\begin{array}{l}0.584^{\star *} \\
{[0.284]}\end{array}$ & $\begin{array}{l}-0.044 \\
{[0.060]}\end{array}$ \\
\hline 1 if single & $\begin{array}{c}0.021 \\
{[0.070]}\end{array}$ & $\begin{array}{c}0.476 \\
{[0.467]}\end{array}$ & $\begin{array}{l}-0.038 \\
{[0.167]}\end{array}$ & $\begin{array}{c}0.074 \\
{[0.093]}\end{array}$ & $\begin{array}{c}0.109 \\
{[0.236]}\end{array}$ & \\
\hline 1 if divorced or widowed & $\begin{array}{l}-0.009 \\
{[0.035]}\end{array}$ & $\begin{array}{c}0.014 \\
{[0.093]}\end{array}$ & $\begin{array}{l}-0.081 \\
{[0.074]}\end{array}$ & $\begin{array}{l}-0.005 \\
{[0.050]}\end{array}$ & $\begin{array}{c}0.004 \\
{[0.132]}\end{array}$ & $\begin{array}{l}-0.056 \\
{[0.071]}\end{array}$ \\
\hline 1 if 1 child & $\begin{array}{l}-0.011 \\
{[0.053]}\end{array}$ & $\begin{array}{c}0.434 \\
{[0.507]}\end{array}$ & $\begin{array}{l}-0.064 \\
{[0.086]}\end{array}$ & $\begin{array}{c}0.035 \\
{[0.071]}\end{array}$ & $\begin{array}{c}0.078 \\
{[0.207]}\end{array}$ & $\begin{array}{c}0.418 \\
{[0.253]}\end{array}$ \\
\hline 1 if more than 1 child & $\begin{array}{c}0.042 \\
{[0.057]}\end{array}$ & $\begin{array}{c}0.487 \\
{[0.498]}\end{array}$ & $\begin{array}{l}-0.055 \\
{[0.096]}\end{array}$ & $\begin{array}{c}0.080 \\
{[0.076]}\end{array}$ & $\begin{array}{c}0.052 \\
{[0.236]}\end{array}$ & $\begin{array}{l}0.444^{*} \\
{[0.254]}\end{array}$ \\
\hline Service staff & $\begin{array}{c}-0.731^{* * *} \\
{[0.034]}\end{array}$ & & & & & \\
\hline Engineers & $\begin{array}{c}-0.064^{* *} \\
{[0.030]}\end{array}$ & & & & & \\
\hline Accountants & $\begin{array}{c}0.401^{* * *} \\
{[0.060]}\end{array}$ & & & & & \\
\hline Managers & $\begin{array}{c}0.662^{* \star *} \\
{[0.051]}\end{array}$ & & & & & \\
\hline Constant & $\begin{array}{c}-0.622 \\
{[0.456]}\end{array}$ & $\begin{array}{l}-1.281 \\
{[2.150]}\end{array}$ & $\begin{array}{l}-0.015 \\
{[0.924]}\end{array}$ & $\begin{array}{l}-0.252 \\
{[0.583]}\end{array}$ & $\begin{array}{c}3.422 \\
{[3.383]}\end{array}$ & $\begin{array}{c}7.886 \\
{[5.539]}\end{array}$ \\
\hline Observations & 3040 & 213 & 790 & 1838 & 76 & 123 \\
\hline R-squared & 0.35 & 0.1 & 0.06 & 0.24 & 0.49 & 0.16 \\
\hline
\end{tabular}

OLS Estimates. Standard errors in brackets

${ }^{*}$ significant at $10 \%$; ${ }^{* *}$ significant at $5 \%$; ${ }^{* * *}$ significant at $1 \%$ 
Table 5: Shares of Monthly Compensation Components

\begin{tabular}{ccccc}
\hline \hline Year & $\begin{array}{c}\text { Monthly } \\
\text { Wage }\end{array}$ & $\begin{array}{c}\text { Monthly } \\
\text { Bonus }\end{array}$ & Extra Bonus & Other Bonus \\
\hline 1997 & 0.830 & 0.080 & 0.051 & 0.039 \\
1998 & 0.916 & 0.059 & 0.000 & 0.025 \\
1999 & 0.870 & 0.066 & 0.043 & 0.021 \\
2000 & 0.854 & 0.066 & 0.042 & 0.038 \\
2001 & 0.797 & 0.081 & 0.098 & 0.025 \\
2002 & 0.776 & 0.095 & 0.088 & 0.041 \\
\hline \hline
\end{tabular}

Table 6

Transition probabilities between quintiles of real wages in 1997 and 2002 (in \%); all continuous employees

\begin{tabular}{|c|c|c|c|c|c|c|c|}
\hline \multicolumn{8}{|c|}{ Quintile in real wage distribution (2002) } \\
\hline \multirow{6}{*}{ 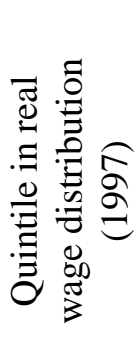 } & & 1 & 2 & 3 & 4 & 5 & $\mathrm{~N}(1997)$ \\
\hline & 1 & 57.89 & 30.47 & 8.59 & 1.39 & 1.66 & 361 \\
\hline & 2 & 28.5 & 34.35 & 25 & 10.28 & 1.87 & 428 \\
\hline & 3 & 4.81 & 19.24 & 34.87 & 35.27 & 5.81 & 499 \\
\hline & 4 & 0.73 & 5.13 & 12.96 & 49.39 & 31.78 & 409 \\
\hline & 5 & 0 & 0.49 & 4.62 & 22.38 & $\mathbf{7 2 . 5 1}$ & 411 \\
\hline
\end{tabular}


Table 7: Real wage growth 1997-2002

\begin{tabular}{|c|c|c|c|}
\hline & (1) & (2) & (3) \\
\hline Tenure in years & $\begin{array}{c}-0.038^{\star \star *} \\
{[0.013]}\end{array}$ & $\begin{array}{c}-0.029^{* * *} \\
{[0.009]}\end{array}$ & $\begin{array}{c}-0.020^{\star *} \\
{[0.009]}\end{array}$ \\
\hline Tenure squared/100 in years & $\begin{array}{l}0.160^{\star *} \\
{[0.077]}\end{array}$ & $\begin{array}{c}0.155^{\star \star *} \\
{[0.053]}\end{array}$ & $\begin{array}{l}0.101^{\star *} \\
{[0.052]}\end{array}$ \\
\hline Tenure cube $/ 1000$ in years & $\begin{array}{l}-0.022^{*} \\
{[0.013]}\end{array}$ & $\begin{array}{c}-0.022^{\star *} \\
{[0.009]}\end{array}$ & $\begin{array}{l}-0.013 \\
{[0.009]}\end{array}$ \\
\hline Age in years & $\begin{array}{c}0.04 \\
{[0.052]}\end{array}$ & $\begin{array}{l}-0.001 \\
{[0.036]}\end{array}$ & $\begin{array}{l}-0.016 \\
{[0.034]}\end{array}$ \\
\hline Age squared/100 in years & $\begin{array}{c}-0.119 \\
{[0.124]}\end{array}$ & $\begin{array}{c}-0.005 \\
{[0.086]}\end{array}$ & $\begin{array}{c}0.039 \\
{[0.081]}\end{array}$ \\
\hline Age cube /1000 in years & $\begin{array}{c}0.011 \\
{[0.010]}\end{array}$ & $\begin{array}{c}0.000 \\
{[0.007]}\end{array}$ & $\begin{array}{l}-0.003 \\
{[0.006]}\end{array}$ \\
\hline Basic professional & $\begin{array}{c}0.000 \\
{[0.028]}\end{array}$ & $\begin{array}{l}-0.008 \\
{[0.019]}\end{array}$ & $\begin{array}{c}0.000 \\
{[0.019]}\end{array}$ \\
\hline Secondary general & $\begin{array}{c}-0.012 \\
{[0.024]}\end{array}$ & $\begin{array}{c}0.024 \\
{[0.017]}\end{array}$ & $\begin{array}{c}0.016 \\
{[0.016]}\end{array}$ \\
\hline Secondary professional & $\begin{array}{c}0.032 \\
{[0.023]}\end{array}$ & $\begin{array}{c}0.097^{* * *} \\
{[0.016]}\end{array}$ & $\begin{array}{l}0.037^{\star \star} \\
{[0.019]}\end{array}$ \\
\hline Higher incomplete & $\begin{array}{c}0.056 \\
{[0.057]}\end{array}$ & $\begin{array}{c}0.144^{\star * *} \\
{[0.039]}\end{array}$ & $\begin{array}{l}0.066^{\star} \\
{[0.040]}\end{array}$ \\
\hline Higher & $\begin{array}{c}0.023 \\
{[0.024]}\end{array}$ & $\begin{array}{c}0.131^{* * *} \\
{[0.017]}\end{array}$ & $\begin{array}{l}0.047^{* *} \\
{[0.022]}\end{array}$ \\
\hline 1 if female & $\begin{array}{c}0.087^{\star * *} \\
{[0.016]}\end{array}$ & $\begin{array}{c}-0.035^{\star \star *} \\
{[0.012]}\end{array}$ & $\begin{array}{c}-0.050^{\star \star \star} \\
{[0.012]}\end{array}$ \\
\hline 1 if single & $\begin{array}{l}-0.061 \\
{[0.080]}\end{array}$ & $\begin{array}{l}-0.045 \\
{[0.055]}\end{array}$ & $\begin{array}{l}-0.057 \\
{[0.053]}\end{array}$ \\
\hline 1 if divorced or widowed & $\begin{array}{l}-0.015 \\
{[0.027]}\end{array}$ & $\begin{array}{c}-0.043^{* *} \\
{[0.019]}\end{array}$ & $\begin{array}{c}-0.044^{* *} \\
{[0.018]}\end{array}$ \\
\hline 1 if 1 child & $\begin{array}{c}0.098 \\
{[0.062]}\end{array}$ & $\begin{array}{c}0.056 \\
{[0.043]}\end{array}$ & $\begin{array}{c}0.045 \\
{[0.041]}\end{array}$ \\
\hline 1 if more than 1 child & $\begin{array}{c}0.063 \\
{[0.064]}\end{array}$ & $\begin{array}{c}0.059 \\
{[0.044]}\end{array}$ & $\begin{array}{c}0.047 \\
{[0.042]}\end{array}$ \\
\hline
\end{tabular}

Position in firm-level wage distribution:

$\begin{array}{lc}\text { 1st decile } & 0.563^{\star * *} \\ \text { 2nd decile } & {[0.022]} \\ & 0.218^{\star \star *} \\ \text { 3rd decile } & {[0.024]} \\ & 0.119^{\star * *} \\ \text { 4th decile } & {[0.023]} \\ & 0.033 \\ \text { 6th decile } & {[0.023]} \\ & -0.098^{\star \star *} \\ \text { 7th decile } & {[0.022]} \\ & -0.090^{\star \star \star} \\ \text { 8th decile } & {[0.023]} \\ & -0.184^{\star \star \star} \\ \text { 9th decile } & {[0.024]} \\ & -0.195^{\star \star *} \\ \text { 10th decile } & {[0.023]} \\ & -0.304^{\star \star *} \\ & {[0.024]}\end{array}$


Position in employee category specific wage distribution:

\begin{tabular}{|c|c|c|c|}
\hline 1st decile & & & $\begin{array}{c}0.559^{* * *} \\
{[0.021]}\end{array}$ \\
\hline 2nd decile & & & $\begin{array}{c}0.251^{* * *} \\
{[0.020]}\end{array}$ \\
\hline 3rd decile & & & $\begin{array}{c}0.183^{\star \star \star} \\
{[0.022]}\end{array}$ \\
\hline 4th decile & & & $\begin{array}{c}0.134^{* * *} \\
{[0.020]}\end{array}$ \\
\hline 6th decile & & & $\begin{array}{c}0.01 \\
{[0.022]}\end{array}$ \\
\hline 7th decile & & & $\begin{array}{c}-0.088^{* * *} \\
{[0.021]}\end{array}$ \\
\hline 8th decile & & & $\begin{array}{c}-0.193^{* * *} \\
{[0.022]}\end{array}$ \\
\hline 9th decile & & & $\begin{array}{c}-0.154^{* * *} \\
{[0.020]}\end{array}$ \\
\hline 10th decile & & & $\begin{array}{c}-0.291^{\star * *} \\
{[0.021]} \\
0.286^{\star \star *} \\
{[0.018]} \\
0.151^{* \star *} \\
{[0.018]} \\
-0.078^{\star *} \\
{[0.039]} \\
-0.089^{\star * *} \\
{[0.028]}\end{array}$ \\
\hline & $\begin{array}{l}-0.425 \\
{[0.699]}\end{array}$ & $\begin{array}{l}-0.056 \\
{[0.482]}\end{array}$ & $\begin{array}{c}0.015 \\
{[0.459]}\end{array}$ \\
\hline & 1824 & 1824 & 1824 \\
\hline & 0.07 & 0.56 & 0.61 \\
\hline
\end{tabular}

Service staff

Engineers

Accountants

Managers

Constant

Observations

R-squared

Standard errors in brackets

${ }^{*}$ significant at $10 \%$; ${ }^{* *}$ significant at $5 \% ;{ }^{* * *}$ significant at $1 \%$ 


\begin{tabular}{|c|c|c|c|c|c|}
\hline & $\begin{array}{l}\text { Service staff } \\
\text { (1) }\end{array}$ & $\begin{array}{l}\text { Engineers } \\
\text { (2) }\end{array}$ & $\begin{array}{c}\text { Production } \\
\text { workers } \\
\text { (3) }\end{array}$ & $\begin{array}{c}\text { Accountants } \\
\text { (4) }\end{array}$ & $\begin{array}{c}\text { Managers } \\
\text { (5) }\end{array}$ \\
\hline Tenure in years & $\begin{array}{c}-0.143^{\star *} \\
{[0.069]}\end{array}$ & $\begin{array}{c}0.013 \\
{[0.011]}\end{array}$ & $\begin{array}{c}-0.027^{* *} \\
{[0.013]}\end{array}$ & $\begin{array}{c}-0.239 \\
{[0.157]}\end{array}$ & $\begin{array}{c}-0.025 \\
{[0.024]}\end{array}$ \\
\hline Tenure squared/100 in years & $\begin{array}{c}0.982^{*} \\
{[0.553]}\end{array}$ & $\begin{array}{c}-0.082 \\
{[0.066]}\end{array}$ & $\begin{array}{c}0.141^{*} \\
{[0.075]}\end{array}$ & $\begin{array}{c}1.683 \\
{[1.089]}\end{array}$ & $\begin{array}{c}0.093 \\
{[0.142]}\end{array}$ \\
\hline Tenure cube $/ 1000$ in years & $\begin{array}{c}-0.209 \\
{[0.134]}\end{array}$ & $\begin{array}{c}0.015 \\
{[0.012]}\end{array}$ & $\begin{array}{c}-0.019 \\
{[0.013]}\end{array}$ & $\begin{array}{l}-0.335 \\
{[0.231]}\end{array}$ & $\begin{array}{c}-0.008 \\
{[0.025]}\end{array}$ \\
\hline Age in years & $\begin{array}{c}-0.234 \\
{[0.148]}\end{array}$ & $\begin{array}{c}-0.02 \\
{[0.033]}\end{array}$ & $\begin{array}{c}0.046 \\
{[0.055]}\end{array}$ & $\begin{array}{c}-0.532 \\
{[1.170]}\end{array}$ & $\begin{array}{c}0.914^{*} \\
{[0.468]}\end{array}$ \\
\hline Age squared/100 in years & $\begin{array}{c}0.55 \\
{[0.348]}\end{array}$ & $\begin{array}{c}0.042 \\
{[0.076]}\end{array}$ & $\begin{array}{c}-0.103 \\
{[0.132]}\end{array}$ & $\begin{array}{c}1.08 \\
{[2.834]}\end{array}$ & $\begin{array}{l}-1.978^{*} \\
{[1.029]}\end{array}$ \\
\hline Age cube /1000 in years & $\begin{array}{c}-0.042 \\
{[0.027]}\end{array}$ & $\begin{array}{c}-0.003 \\
{[0.006]}\end{array}$ & $\begin{array}{c}0.007 \\
{[0.010]}\end{array}$ & $\begin{array}{c}-0.071 \\
{[0.225]}\end{array}$ & $\begin{array}{c}0.141^{*} \\
{[0.075]}\end{array}$ \\
\hline Basic professional & $\begin{array}{c}0.058 \\
{[0.050]}\end{array}$ & $\begin{array}{c}-0.460^{* * *} \\
{[0.146]}\end{array}$ & $\begin{array}{c}-0.018 \\
{[0.023]}\end{array}$ & & \\
\hline Secondary general & $\begin{array}{c}0.004 \\
{[0.052]}\end{array}$ & & $\begin{array}{c}-0.001 \\
{[0.019]}\end{array}$ & & \\
\hline Secondary professional & $\begin{array}{c}0.057 \\
{[0.063]}\end{array}$ & $\begin{array}{c}-0.012 \\
{[0.026]}\end{array}$ & $\begin{array}{c}0.028 \\
{[0.024]}\end{array}$ & $\begin{array}{c}0.172 \\
{[0.447]}\end{array}$ & $\begin{array}{l}-0.066 \\
{[0.068]}\end{array}$ \\
\hline Higher incomplete & $\begin{array}{l}-0.029 \\
{[0.235]}\end{array}$ & & $\begin{array}{c}0.053 \\
{[0.103]}\end{array}$ & $\begin{array}{c}-0.011 \\
{[0.813]}\end{array}$ & \\
\hline Higher & $\begin{array}{c}0.125 \\
{[0.163]}\end{array}$ & $\begin{array}{l}-0.005 \\
{[0.026]}\end{array}$ & $\begin{array}{c}-0.039 \\
{[0.047]}\end{array}$ & $\begin{array}{c}0.337 \\
{[0.483]}\end{array}$ & $\begin{array}{l}-0.025 \\
{[0.068]}\end{array}$ \\
\hline 1 if female & $\begin{array}{c}-0.036 \\
{[0.041]}\end{array}$ & $\begin{array}{c}0.006 \\
{[0.011]}\end{array}$ & $\begin{array}{c}-0.111^{* * *} \\
{[0.021]}\end{array}$ & $\begin{array}{c}-0.29 \\
{[0.427]}\end{array}$ & $\begin{array}{l}-0.015 \\
{[0.028]}\end{array}$ \\
\hline 1 if single & $\begin{array}{c}-0.247 \\
{[0.230]}\end{array}$ & $\begin{array}{c}0.031 \\
{[0.075]}\end{array}$ & $\begin{array}{c}0.139 \\
{[0.087]}\end{array}$ & & \\
\hline 1 if divorced or widowed & $\begin{array}{l}-0.101^{*} \\
{[0.056]}\end{array}$ & $\begin{array}{l}-0.016 \\
{[0.029]}\end{array}$ & $\begin{array}{l}-0.025 \\
{[0.026]}\end{array}$ & $\begin{array}{l}-0.441^{* *} \\
{[0.192]}\end{array}$ & $\begin{array}{c}0.002 \\
{[0.028]}\end{array}$ \\
\hline 1 if 1 child & $\begin{array}{c}-0.066 \\
{[0.051]}\end{array}$ & $\begin{array}{c}-0.028 \\
{[0.035]}\end{array}$ & $\begin{array}{c}0.232^{* * *} \\
{[0.073]}\end{array}$ & $\begin{array}{c}0.067 \\
{[0.166]}\end{array}$ & $\begin{array}{c}-0.013 \\
{[0.020]}\end{array}$ \\
\hline 1 if more than 1 child & & $\begin{array}{l}-0.012 \\
{[0.039]}\end{array}$ & $\begin{array}{l}0.219^{* * *} \\
{[0.074]}\end{array}$ & & \\
\hline $\begin{array}{l}\text { Position in employee category } \\
\text { specific wage distribution: }\end{array}$ & & & & & \\
\hline 1st decile & $\begin{array}{c}0.617^{\star \star *} \\
{[0.085]}\end{array}$ & $\begin{array}{c}0.403^{\star \star *} \\
{[0.022]}\end{array}$ & $\begin{array}{c}0.674^{\star \star *} \\
{[0.032]}\end{array}$ & $\begin{array}{c}0.466 \\
{[0.294]}\end{array}$ & $\begin{array}{c}0.419^{\star * *} \\
{[0.041]}\end{array}$ \\
\hline 2nd decile & $\begin{array}{l}0.287^{* * *} \\
{[0.080]}\end{array}$ & $\begin{array}{l}0.213^{\star * *} \\
{[0.022]}\end{array}$ & $\begin{array}{l}0.270^{* * *} \\
{[0.029]}\end{array}$ & $\begin{array}{c}0.264 \\
{[0.275]}\end{array}$ & $\begin{array}{l}0.278^{* * *} \\
{[0.047]}\end{array}$ \\
\hline 3rd decile & $\begin{array}{c}-0.037 \\
{[0.082]}\end{array}$ & $\begin{array}{c}0.161^{\star * *} \\
{[0.022]}\end{array}$ & $\begin{array}{c}0.202^{* * *} \\
{[0.034]}\end{array}$ & $\begin{array}{c}-0.003 \\
{[0.363]}\end{array}$ & $\begin{array}{c}0.254^{* * *} \\
{[0.043]}\end{array}$ \\
\hline 4th decile & $\begin{array}{c}0.259^{\star * *} \\
{[0.088]}\end{array}$ & $\begin{array}{c}0.085^{\star * *} \\
{[0.022]}\end{array}$ & $\begin{array}{c}0.137^{* * *} \\
{[0.030]}\end{array}$ & $\begin{array}{c}0.052 \\
{[0.286]}\end{array}$ & $\begin{array}{l}0.103^{* *} \\
{[0.043]}\end{array}$ \\
\hline 6th decile & $\begin{array}{c}-0.083 \\
{[0.083]}\end{array}$ & $\begin{array}{c}-0.087^{\star * *} \\
{[0.023]}\end{array}$ & $\begin{array}{l}0.086^{\star *} \\
{[0.035]}\end{array}$ & $\begin{array}{c}0.107 \\
{[0.310]}\end{array}$ & $\begin{array}{c}-0.147^{\star * *} \\
{[0.045]}\end{array}$ \\
\hline 7th decile & $\begin{array}{c}-0.314^{\star * *} \\
{[0.084]}\end{array}$ & $\begin{array}{c}-0.140^{\star * *} \\
{[0.022]}\end{array}$ & $\begin{array}{l}-0.033 \\
{[0.031]}\end{array}$ & $\begin{array}{l}-0.175 \\
{[0.262]}\end{array}$ & $\begin{array}{c}-0.116^{\star * *} \\
{[0.043]}\end{array}$ \\
\hline 8th decile & $\begin{array}{l}-0.550 * * * \\
{[0.085]}\end{array}$ & $\begin{array}{l}-0.186^{* * *} \\
{[0.023]}\end{array}$ & $\begin{array}{l}-0.162^{* * *} \\
{[0.034]}\end{array}$ & $\begin{array}{l}-0.043 \\
{[0.344]}\end{array}$ & $\begin{array}{c}-0.123^{* * *} \\
{[0.039]}\end{array}$ \\
\hline 9th decile & $\begin{array}{c}-0.621^{* * *} \\
{[0.084]}\end{array}$ & $\begin{array}{c}-0.189^{* * *} \\
{[0.022]}\end{array}$ & $\begin{array}{c}-0.086^{* * *} \\
{[0.030]}\end{array}$ & $\begin{array}{c}0.042 \\
{[0.274]}\end{array}$ & $\begin{array}{c}-0.158^{* * *} \\
{[0.050]}\end{array}$ \\
\hline 10th decile & $\begin{array}{c}-0.761^{\star \star *} \\
{[0.084]}\end{array}$ & $\begin{array}{c}-0.287^{* * *} \\
{[0.023]}\end{array}$ & $\begin{array}{c}-0.241^{* * *} \\
{[0.032]}\end{array}$ & $\begin{array}{c}-0.096 \\
{[0.295]}\end{array}$ & $\begin{array}{c}-0.268^{* * *} \\
{[0.044]}\end{array}$ \\
\hline Constant & $\begin{array}{l}4.054^{\star} \\
{[2.070]} \\
\end{array}$ & $\begin{array}{c}0.224 \\
{[0.438]} \\
\end{array}$ & $\begin{array}{l}-1.018 \\
{[0.733]} \\
\end{array}$ & $\begin{array}{r}8.929 \\
{[16.054]} \\
\end{array}$ & $\begin{array}{c}-14.044^{* *} \\
{[7.005]}\end{array}$ \\
\hline $\begin{array}{l}\text { Observations } \\
\text { R-squared }\end{array}$ & $\begin{array}{l}151 \\
0.83 \\
\end{array}$ & $\begin{array}{l}611 \\
0.75\end{array}$ & $\begin{array}{l}934 \\
0.53\end{array}$ & $\begin{array}{c}36 \\
0.69\end{array}$ & $\begin{array}{l}92 \\
0.9\end{array}$ \\
\hline
\end{tabular}

Standard errors in brackets

${ }^{*}$ significant at $10 \%$; ${ }^{* *}$ significant at $5 \%$; ${ }^{* *}$ significant at $1 \%$ 
Table 9

Summary statistics of real wage arrears for 1998 by employee type in thousands of Rubles (A) and in months of 1997 wages (B)

\begin{tabular}{|c|c|c|c|c|c|c|c|}
\hline Type & $\mathrm{N}$ & mean & Std. dev. & $50 \%$ & $75 \%$ & $90 \%$ & $\max$ \\
\hline \multicolumn{8}{|c|}{ All employees } \\
\hline A & 3408 & 0.099 & 0.198 & 0 & 0.120 & 0.273 & 2.786 \\
\hline B & 3395 & 0.078 & 0.130 & 0 & 0.116 & 0.313 & 1.140 \\
\hline \multicolumn{8}{|c|}{ Service workers } \\
\hline A & 237 & 0.088 & 0.041 & 0.094 & 0.110 & 0.131 & 0.210 \\
\hline $\mathrm{B}$ & 236 & 0.130 & 0.051 & 0.136 & 0.139 & 0.194 & 0.298 \\
\hline \multicolumn{8}{|c|}{ Engineers } \\
\hline A & 786 & 0.112 & 0.070 & 0.120 & 0.168 & 0.210 & 0.630 \\
\hline B & 779 & 0.116 & 0.046 & 0.115 & 0.116 & 0.162 & 0.670 \\
\hline \multicolumn{8}{|c|}{ Workers } \\
\hline $\mathrm{A}$ & 2179 & 0.073 & 0.212 & 0 & 0 & 0.368 & 1.840 \\
\hline B & 2175 & 0.051 & 0.142 & 0 & 0 & 0.333 & 0.907 \\
\hline \multicolumn{8}{|c|}{ Accountants } \\
\hline A & 76 & 0.436 & 0.270 & 0.488 & 0.625 & 0.757 & 0.893 \\
\hline B & 75 & 0.309 & 0.201 & 0.371 & 0.373 & 0.447 & 1.140 \\
\hline \multicolumn{8}{|c|}{ Managers } \\
\hline A & 130 & 0.187 & 0.322 & 0.160 & 0.189 & 0.199 & 2.786 \\
\hline B & 130 & 0.066 & 0.112 & 0.055 & 0.056 & 0.056 & 0.670 \\
\hline
\end{tabular}

Source: Authors' calculations

\section{Table 10}

Tobit regressions with dependent variables: real wage arrears for 1998 in thousands of Rubles and in months of 1997 wages

\begin{tabular}{|c|c|c|c|c|}
\hline \multirow[t]{2}{*}{ regressor } & \multicolumn{4}{|c|}{ Dependent variable } \\
\hline & real arrears & real arrears & $\begin{array}{c}\text { real arrears / } \\
\text { monthly } 97 \text { wages }\end{array}$ & $\begin{array}{c}\text { real arrears / } \\
\text { monthly } 97 \text { wages }\end{array}$ \\
\hline constant & $\begin{array}{c}0.055 \\
(0.018)^{*}\end{array}$ & $\begin{array}{c}0.024 \\
(0.026)\end{array}$ & $\begin{array}{c}0.067 \\
(0.011)^{*}\end{array}$ & $\begin{array}{c}0.140 \\
(0.017)^{*}\end{array}$ \\
\hline real wage & $\begin{array}{c}-0.037 \\
(0.011)^{*}\end{array}$ & $\begin{array}{c}0.051 \\
(0.015)^{*}\end{array}$ & $\begin{array}{c}-0.089 \\
(0.007)^{*}\end{array}$ & $\begin{array}{c}-0.039 \\
(0.010)^{*}\end{array}$ \\
\hline engineers & & $\begin{array}{c}0.030 \\
(0.028)\end{array}$ & & $\begin{array}{c}0.010 \\
(0.018)\end{array}$ \\
\hline workers & & $\begin{array}{c}-0.405 \\
(0.031)^{*}\end{array}$ & & $\begin{array}{c}-0.272 \\
(0.020)^{*}\end{array}$ \\
\hline accountants & & $\begin{array}{c}0.293 \\
(0.050)^{*}\end{array}$ & & $\begin{array}{c}0.199 \\
(0.033)^{*}\end{array}$ \\
\hline managers & & $\begin{array}{l}-0.037 \\
(0.053)\end{array}$ & & $\begin{array}{c}0.002 \\
(0.035)\end{array}$ \\
\hline Diagnostics & $\begin{array}{c}\mathrm{N}=3395 \\
\mathrm{Chi}^{2}(1)=10.22 \\
\text { Pseudo } \mathrm{R}^{2}=0.002\end{array}$ & $\begin{array}{c}\mathrm{N}=3395 \\
\operatorname{Chi}^{2}(5)=846.88 \\
\text { Pseudo } \mathrm{R}^{2}=0.234\end{array}$ & $\begin{array}{c}\mathrm{N}=3395 \\
\operatorname{Chi}^{2}(1)=129.73 \\
\text { Pseudo } \mathrm{R}^{2}=0.049\end{array}$ & $\begin{array}{c}\mathrm{N}=3395 \\
\mathrm{Chi}^{2}(5)=997.07 \\
\text { Pseudo } \mathrm{R}^{2}=0.377\end{array}$ \\
\hline
\end{tabular}


Table 11

Evolution of earnings inequality measured by Gini coefficients

(1)

(2)

(3)

(4)

(5)

(6)

Panel a: Wages

\begin{tabular}{ccccccc} 
Year & $\begin{array}{c}\text { Entire } \\
\text { workforce }\end{array}$ & $\begin{array}{c}\text { Service } \\
\text { staff }\end{array}$ & Engineers & Workers & Accountants & Managers \\
\hline 1997 & 0.2801 & 0.2474 & 0.2294 & 0.2507 & 0.1912 & 0.1367 \\
1998 & 0.251 & 0.1484 & 0.2239 & 0.2003 & 0.1417 & 0.1082 \\
1999 & 0.2453 & 0.0853 & 0.1954 & 0.1854 & 0.1267 & 0.1202 \\
2000 & 0.2456 & 0.0649 & 0.1786 & 0.1945 & 0.1705 & 0.072 \\
2001 & 0.2189 & 0.055 & 0.1679 & 0.1792 & 0.1583 & 0.0438 \\
2002 & 0.1995 & 0.1618 & 0.1437 & 0.1725 & 0.1409 & 0.0482
\end{tabular}

Panel b: Total compensation

\begin{tabular}{ccccccc} 
Year & $\begin{array}{c}\text { Entire } \\
\text { workforce }\end{array}$ & $\begin{array}{c}\text { Service } \\
\text { staff }\end{array}$ & Engineers & Workers & Accountants & Managers \\
\hline 1997 & 0.2928 & 0.2416 & 0.2293 & 0.2456 & 0.1903 & 0.1488 \\
1998 & 0.2547 & 0.1474 & 0.2248 & 0.2015 & 0.1423 & 0.1077 \\
1999 & 0.2444 & 0.0855 & 0.1964 & 0.1823 & 0.131 & 0.1202 \\
2000 & 0.2464 & 0.0669 & 0.1792 & 0.1972 & 0.1787 & 0.073 \\
2001 & 0.2271 & 0.0684 & 0.1681 & 0.1778 & 0.1696 & 0.0447 \\
2002 & 0.2211 & 0.162 & 0.1455 & 0.1845 & 0.1454 & 0.0484 \\
\hline \hline
\end{tabular}


Table 12

Gini decomposition by income source

\begin{tabular}{ccccc}
\hline \hline Year & $\begin{array}{c}\text { Monthly } \\
\text { Wage }\end{array}$ & $\begin{array}{c}\text { Monthly } \\
\text { Bonus }\end{array}$ & $\begin{array}{c}\text { Extra } \\
\text { Bonus }\end{array}$ & $\begin{array}{c}\text { Other } \\
\text { Bonus }\end{array}$ \\
\hline \multicolumn{5}{c}{ Gini by income source } \\
1997 & 0.2802 & 0.8069 & 0.63 & 0.725 \\
1998 & 0.251 & 0.7933 & - & 0.7027 \\
1999 & 0.2453 & 0.7846 & 0.5467 & 0.7788 \\
2000 & 0.2457 & 0.7759 & 0.5488 & 0.7271 \\
2001 & 0.219 & 0.7658 & 0.352 & 0.7367 \\
2002 & 0.1996 & 0.758 & 0.2724 & 0.7209 \\
Gini correlation of income source with distribution of total income \\
1997 & 0.9752 & 0.6052 & 0.5787 & 0.2968 \\
1998 & 0.9893 & 0.4063 & - & 0.4621 \\
1999 & 0.9895 & 0.2838 & 0.5298 & 0.371 \\
2000 & 0.9775 & 0.3499 & 0.3805 & 0.5315 \\
2001 & 0.9711 & 0.5007 & 0.6761 & 0.192 \\
2002 & 0.9586 & 0.5955 & 0.8062 & 0.3527 \\
\hline \hline
\end{tabular}


Table 13

Contributions of source incomes on inequality

\begin{tabular}{ccccc}
\hline \hline Year & $\begin{array}{c}\text { Monthly } \\
\text { Wage }\end{array}$ & $\begin{array}{c}\text { Monthly } \\
\text { Bonus }\end{array}$ & $\begin{array}{c}\text { Extra } \\
\text { Bonus }\end{array}$ & $\begin{array}{c}\text { Other } \\
\text { Bonus }\end{array}$
\end{tabular}

Share of source income in total inequality

$\begin{array}{lcccc}1997 & 0.7749 & 0.1333 & 0.063 & 0.0288 \\ 1998 & 0.8929 & 0.0756 & - & 0.0315 \\ 1999 & 0.8643 & 0.06 & 0.0513 & 0.0245 \\ 2000 & 0.8324 & 0.0731 & 0.0354 & 0.0591 \\ 2001 & 0.7462 & 0.1364 & 0.1021 & 0.0153 \\ 2002 & 0.6707 & 0.1947 & 0.0875 & 0.047\end{array}$

Inequality components as a fraction of income shares

$\begin{array}{lcccc}1997 & 0.9333 & 1.6677 & 1.2451 & 0.7349 \\ 1998 & 0.9748 & 1.2748 & - & 1.275 \\ 1999 & 0.9932 & 0.911 & 1.185 & 1.1823 \\ 2000 & 0.9745 & 1.1016 & 0.8473 & 1.5682 \\ 2001 & 0.936 & 1.6878 & 1.0476 & 0.6227 \\ 2002 & 0.8649 & 2.041 & 0.9928 & 1.1495\end{array}$

Impact of $1 \%$ change in income source on inequality

\begin{tabular}{ccccc}
1997 & -0.0554 & 0.0534 & 0.0124 & -0.0104 \\
1998 & -0.0231 & 0.0163 & - & 0.0068 \\
1999 & -0.0059 & -0.0059 & 0.008 & 0.0038 \\
2000 & -0.0218 & 0.0067 & -0.0064 & 0.0214 \\
2001 & -0.051 & 0.0556 & 0.0046 & -0.0093 \\
2002 & -0.1048 & 0.0993 & -0.0006 & 0.0061 \\
\hline
\end{tabular}


Table 14

General Entropy Index (GEI) and its decomposition into within and between parts
(1)
(2)
(3)
(4)
(5)
(6)

\begin{tabular}{ccccccc}
\multirow{2}{*}{ Year } & \multicolumn{3}{c}{ Panel a: Wages } & & GEI(+1) \\
& Total & Within & Between & Total & Within & Between \\
\hline & & & & & & \\
1997 & 0.1904 & 0.1515 & 0.0389 & 0.1263 & 0.0914 & 0.0348 \\
1998 & 0.1379 & 0.097 & 0.0409 & 0.1001 & 0.0637 & 0.0363 \\
1999 & 0.1151 & 0.07 & 0.0451 & 0.0958 & 0.0538 & 0.042 \\
2000 & 0.1082 & 0.0626 & 0.0456 & 0.0938 & 0.0539 & 0.0399 \\
2001 & 0.095 & 0.0528 & 0.0421 & 0.076 & 0.0444 & 0.0315 \\
2002 & 0.0762 & 0.0544 & 0.0217 & 0.0645 & 0.0399 & 0.0245
\end{tabular}

Panel b: Total compensation

\begin{tabular}{ccccccc} 
Year & \multicolumn{3}{c}{ GEI(-1) } & \multicolumn{3}{c}{ GEI $(+1)$} \\
& Total & Within & Between & Total & Within & Between \\
\hline & & & & & & \\
1997 & 0.195 & 0.1453 & 0.0497 & 0.1446 & 0.086 & 0.0348 \\
1998 & 0.1379 & 0.0976 & 0.0402 & 0.1061 & 0.0636 & 0.0363 \\
1999 & 0.1144 & 0.0688 & 0.0456 & 0.0991 & 0.0525 & 0.042 \\
2000 & 0.1086 & 0.0651 & 0.0434 & 0.0987 & 0.0546 & 0.0399 \\
2001 & 0.1017 & 0.0554 & 0.0462 & 0.0853 & 0.0435 & 0.0315 \\
2002 & 0.0941 & 0.0636 & 0.0304 & 0.0826 & 0.0433 & 0.0245 \\
\hline \hline
\end{tabular}




\section{Appendix}

Table A1: Determinants of wages, 2002

\begin{tabular}{|c|c|c|c|c|c|c|}
\hline & \multicolumn{6}{|c|}{ Dependent Variable: log(real wage) in 2002} \\
\hline & $\begin{array}{c}\text { All } \\
\text { employees } \\
(1)\end{array}$ & $\begin{array}{l}\text { Service staff } \\
\text { (2) }\end{array}$ & $\begin{array}{c}\text { Engineers } \\
\text { (3) }\end{array}$ & $\begin{array}{c}\text { Production } \\
\text { workers } \\
(4)\end{array}$ & $\begin{array}{c}\text { Accountants } \\
\text { (5) }\end{array}$ & $\begin{array}{c}\text { Managers } \\
(6)\end{array}$ \\
\hline \multirow[t]{2}{*}{ Tenure in years } & $0.010^{\star *}$ & 0.04 & $0.035^{\star * *}$ & 0.003 & 0.027 & 0.002 \\
\hline & {$[0.004]$} & [0.026] & {$[0.009]$} & [0.006] & [0.028] & [0.013] \\
\hline \multirow[t]{2}{*}{ Tenure squared/100 in years } & -0.039 & $-0.534^{*}$ & $-0.174^{\star * \star}$ & 0.008 & -0.184 & -0.049 \\
\hline & [0.033] & [0.287] & {$[0.063]$} & [0.043] & [0.261] & [0.081] \\
\hline \multirow{2}{*}{ Tenure cube $/ 1000$ in years } & 0.008 & $0.158^{*}$ & $0.027^{\star \star}$ & 0.000 & 0.045 & 0.015 \\
\hline & {$[0.007]$} & {$[0.087]$} & [0.013] & [0.009] & [0.069] & [0.015] \\
\hline \multirow[t]{2}{*}{ Age in years } & $0.111^{* * *}$ & 0.067 & $-0.100^{* \star}$ & $0.142^{* * *}$ & $-0.671^{\star * *}$ & $0.935^{\star * *}$ \\
\hline & {$[0.022]$} & [0.084] & [0.044] & [0.028] & [0.232] & [0.196] \\
\hline \multirow[t]{2}{*}{ Age squared/100 in years } & $-0.248^{\star * *}$ & -0.183 & $0.245^{\star \star}$ & $-0.319^{\star * *}$ & $1.781^{\star \star \star}$ & $-1.935^{\star * *}$ \\
\hline & {$[0.054]$} & [0.207] & [0.108] & {$[0.070]$} & {$[0.597]$} & {$[0.447]$} \\
\hline \multirow[t]{2}{*}{ Age cube $/ 1000$ in years } & $0.018^{* * *}$ & 0.015 & $-0.019^{\star *}$ & $0.024^{\star \star \star}$ & $-0.152^{* * *}$ & $0.132^{\star \star \star}$ \\
\hline & {$[0.004]$} & {$[0.017]$} & {$[0.009]$} & {$[0.006]$} & {$[0.050]$} & {$[0.034]$} \\
\hline \multirow[t]{2}{*}{ Basic professional } & $0.056^{\star \star \star}$ & 0.094 & -0.406 & 0.033 & & \\
\hline & {$[0.018]$} & [0.059] & {$[0.259]$} & {$[0.020]$} & & \\
\hline \multirow[t]{2}{*}{ Secondary general } & $0.056^{\star * *}$ & 0.062 & & $0.041^{\star *}$ & & \\
\hline & {$[0.017]$} & [0.060] & & {$[0.019]$} & & \\
\hline \multirow[t]{2}{*}{ Secondary professional } & $0.087^{\star \star *}$ & 0.085 & -0.011 & $0.073^{\star \star *}$ & $0.711^{* *}$ & -0.024 \\
\hline & {$[0.019]$} & {$[0.070]$} & {$[0.046]$} & [0.022] & {$[0.301]$} & [0.062] \\
\hline \multirow[t]{2}{*}{ Higher incomplete } & $0.096^{\star \star}$ & 0.34 & & 0.044 & $1.152^{* \star *}$ & \\
\hline & [0.045] & [0.305] & & {$[0.080]$} & [0.422] & \\
\hline \multirow[t]{2}{*}{ Higher } & $0.107^{\star * *}$ & 0.271 & 0.026 & $0.066^{*}$ & $0.984^{\star * \star}$ & 0.002 \\
\hline & {$[0.023]$} & {$[0.218]$} & {$[0.046]$} & {$[0.038]$} & {$[0.304]$} & {$[0.061]$} \\
\hline \multirow[t]{2}{*}{1 if female } & $-0.170^{\star * \star}$ & $-0.152^{* * *}$ & $-0.082^{* \star *}$ & $-0.228^{\star * *}$ & 0.292 & 0.004 \\
\hline & {$[0.012]$} & {$[0.049]$} & [0.018] & {$[0.016]$} & [0.204] & [0.019] \\
\hline \multirow[t]{2}{*}{1 if single } & -0.032 & -0.165 & 0.063 & -0.073 & 0.153 & \\
\hline & [0.039] & [0.307] & [0.088] & {$[0.050]$} & [0.215] & \\
\hline \multirow[t]{2}{*}{1 if divorced or widowed } & $-0.072^{\star \star \star}$ & 0.011 & -0.059 & $-0.085^{\star \star \star}$ & -0.23 & -0.017 \\
\hline & {$[0.020]$} & [0.063] & {$[0.051]$} & {$[0.026]$} & [0.144] & [0.024] \\
\hline \multirow[t]{2}{*}{1 if 1 child } & 0.015 & -0.379 & 0.023 & 0.017 & $0.563^{*}$ & -0.044 \\
\hline & [0.034] & {$[0.330]$} & [0.052] & [0.045] & [0.324] & [0.062] \\
\hline 1 if more than 1 child & 0.027 & -0.388 & 0.084 & 0.014 & $0.568^{*}$ & -0.032 \\
\hline & {$[0.037]$} & [0.325] & [0.061] & [0.049] & [0.331] & [0.063] \\
\hline Service staff & $-0.516^{\star * *}$ & & & & & \\
\hline & {$[0.021]$} & & & & & \\
\hline Engineers & -0.014 & & & & & \\
\hline & {$[0.018]$} & & & & & \\
\hline Accountants & $0.152^{\star \star \star}$ & & & & & \\
\hline & {$[0.040]$} & & & & & \\
\hline Managers & $0.679^{\star * \star}$ & & & & & \\
\hline & {$[0.032]$} & & & & & \\
\hline Constant & $-1.655^{\star \star \star}$ & -0.953 & $1.170^{\star *}$ & $-2.032^{* \star *}$ & $6.433^{* *}$ & $-14.020^{\star * *}$ \\
\hline & {$[0.269]$} & [1.094] & {$[0.568]$} & {$[0.339]$} & {$[2.807]$} & [2.822] \\
\hline Observations & 3104 & 213 & 781 & 1929 & 64 & 117 \\
\hline R-squared & 0.42 & 0.21 & 0.1 & 0.24 & 0.56 & 0.47 \\
\hline
\end{tabular}

OLS Estimates. Standard errors in brackets

${ }^{*}$ significant at $10 \%$; ${ }^{* *}$ significant at $5 \%$; ${ }^{* * *}$ significant at $1 \%$ 
Dependent variable: log(real wage) in 1997

10th percentile 20th percentile $\quad$ 30th percentile 40 th percentile $\quad$ 50th percentile $\quad$ 60th percentile 70th percentile 80 th percentile 90 th percentile

\begin{tabular}{|c|c|c|c|c|c|c|c|c|c|}
\hline Tenure in years & $\begin{array}{c}0.026 \\
{[0.016]}\end{array}$ & $\begin{array}{c}0.016 \\
{[0.015]}\end{array}$ & $\begin{array}{l}0.022^{*} \\
{[0.012]}\end{array}$ & $\begin{array}{l}0.025^{\star \star} \\
{[0.011]}\end{array}$ & $\begin{array}{c}0.031^{\star * *} \\
{[0.010]}\end{array}$ & $\begin{array}{c}0.031^{\star * \star} \\
{[0.007]}\end{array}$ & $\begin{array}{c}0.029^{\star \star \star} \\
{[0.008]}\end{array}$ & $\begin{array}{c}0.024^{\star \star \star} \\
{[0.006]}\end{array}$ & $\begin{array}{c}0.024^{\star * *} \\
{[0.007]}\end{array}$ \\
\hline Tenure squared/100 in years & -0.072 & -0.003 & -0.088 & -0.114 & $-0.154^{*}$ & $-0.169^{\star \star \star}$ & $-0.186^{\star \star}$ & $-0.139^{\star *}$ & $-0.121^{*}$ \\
\hline & {$[0.135]$} & {$[0.133]$} & [0.108] & {$[0.096]$} & {$[0.086]$} & [0.063] & {$[0.075]$} & {$[0.055]$} & [0.063] \\
\hline Tenure cube /1000 in years & $\begin{array}{c}0.01 \\
{[0.029]}\end{array}$ & $\begin{array}{c}-0.003 \\
{[0.032]}\end{array}$ & $\begin{array}{c}0.016 \\
{[0.026]}\end{array}$ & $\begin{array}{c}0.022 \\
{[0.023]}\end{array}$ & $\begin{array}{c}0.027 \\
{[0.020]}\end{array}$ & $\begin{array}{l}0.030^{\star \star} \\
{[0.015]}\end{array}$ & $\begin{array}{l}0.037^{\star \star} \\
{[0.018]}\end{array}$ & $\begin{array}{l}0.026^{\star \star} \\
{[0.013]}\end{array}$ & $\begin{array}{c}0.018 \\
{[0.016]}\end{array}$ \\
\hline Age in years & $\begin{array}{c}0.075 \\
{[0.082]}\end{array}$ & $\begin{array}{c}0.003 \\
{[0.072]}\end{array}$ & $\begin{array}{c}0.002 \\
{[0.061]}\end{array}$ & $\begin{array}{c}0.021 \\
{[0.055]}\end{array}$ & $\begin{array}{c}0.034 \\
{[0.050]}\end{array}$ & $\begin{array}{c}0.054 \\
{[0.037]}\end{array}$ & $\begin{array}{c}0.071 \\
{[0.045]}\end{array}$ & $\begin{array}{c}0.04 \\
{[0.033]}\end{array}$ & $\begin{array}{l}-0.006 \\
{[0.039]}\end{array}$ \\
\hline Age squared/100 in years & $\begin{array}{l}-0.136 \\
{[0.223]}\end{array}$ & $\begin{array}{c}0.048 \\
{[0.195]}\end{array}$ & $\begin{array}{c}0.055 \\
{[0.165]}\end{array}$ & $\begin{array}{c}0.014 \\
{[0.149]}\end{array}$ & $\begin{array}{l}-0.031 \\
{[0.134]}\end{array}$ & $\begin{array}{c}-0.077 \\
{[0.100]}\end{array}$ & $\begin{array}{l}-0.119 \\
{[0.120]}\end{array}$ & $\begin{array}{l}-0.051 \\
{[0.089]}\end{array}$ & $\begin{array}{c}0.064 \\
{[0.104]}\end{array}$ \\
\hline Age cube /1000 in years & $\begin{array}{c}0.008 \\
{[0.019]}\end{array}$ & $\begin{array}{c}-0.008 \\
{[0.017]}\end{array}$ & $\begin{array}{c}-0.009 \\
{[0.014]}\end{array}$ & $\begin{array}{c}-0.006 \\
{[0.013]}\end{array}$ & $\begin{array}{l}-0.001 \\
{[0.012]}\end{array}$ & $\begin{array}{c}0.003 \\
{[0.009]}\end{array}$ & $\begin{array}{c}0.006 \\
{[0.010]}\end{array}$ & $\begin{array}{c}0.001 \\
{[0.008]}\end{array}$ & $\begin{array}{c}-0.008 \\
{[0.009]}\end{array}$ \\
\hline Basic professional & $\begin{array}{c}0.077 \\
{[0.066]}\end{array}$ & $\begin{array}{c}0.092 \\
{[0.058]}\end{array}$ & $\begin{array}{c}0.03 \\
{[0.048]}\end{array}$ & $\begin{array}{c}0.026 \\
{[0.042]}\end{array}$ & $\begin{array}{c}0.02 \\
{[0.038]}\end{array}$ & $\begin{array}{c}0.01 \\
{[0.028]}\end{array}$ & $\begin{array}{c}0.04 \\
{[0.032]}\end{array}$ & $\begin{array}{c}0.027 \\
{[0.023]}\end{array}$ & $\begin{array}{c}0.016 \\
{[0.025]}\end{array}$ \\
\hline Secondary general & $\begin{array}{c}0.203^{\star \star \star *} \\
{[0.064]}\end{array}$ & $\begin{array}{c}0.08 \\
{[0.055]}\end{array}$ & $\begin{array}{l}0.102^{\star \star} \\
{[0.046]}\end{array}$ & $\begin{array}{c}0.063 \\
{[0.040]}\end{array}$ & $\begin{array}{l}0.061^{\star} \\
{[0.036]}\end{array}$ & $\begin{array}{c}0.028 \\
{[0.027]}\end{array}$ & $\begin{array}{c}0.038 \\
{[0.031]}\end{array}$ & $\begin{array}{c}0.066^{\star * *} \\
{[0.022]}\end{array}$ & $\begin{array}{l}0.050^{\star \star} \\
{[0.024]}\end{array}$ \\
\hline Secondary professional & $\begin{array}{c}0.266^{\star * *} \\
{[0.069]}\end{array}$ & $\begin{array}{l}0.197^{* * *} \\
{[0.060]}\end{array}$ & $\begin{array}{l}0.108^{\star \star} \\
{[0.049]}\end{array}$ & $\begin{array}{c}0.067 \\
{[0.044]}\end{array}$ & $\begin{array}{c}0.056 \\
{[0.039]}\end{array}$ & $\begin{array}{c}0.038 \\
{[0.029]}\end{array}$ & $\begin{array}{c}0.036 \\
{[0.034]}\end{array}$ & $\begin{array}{c}0.037 \\
{[0.024]}\end{array}$ & $\begin{array}{c}0.04 \\
{[0.026]}\end{array}$ \\
\hline Higher incomplete & $\begin{array}{l}0.354^{\star \star} \\
{[0.140]}\end{array}$ & $\begin{array}{c}0.191 \\
{[0.132]}\end{array}$ & $\begin{array}{c}0.176 \\
{[0.112]}\end{array}$ & $\begin{array}{c}0.118 \\
{[0.099]}\end{array}$ & $\begin{array}{c}0.135 \\
{[0.088]}\end{array}$ & $\begin{array}{c}0.089 \\
{[0.065]}\end{array}$ & $\begin{array}{c}0.099 \\
{[0.075]}\end{array}$ & $\begin{array}{l}0.130^{\star *} \\
{[0.052]}\end{array}$ & $\begin{array}{l}0.103^{*} \\
{[0.054]}\end{array}$ \\
\hline Higher & $\begin{array}{l}0.151^{*} \\
{[0.086]}\end{array}$ & $\begin{array}{l}0.127^{\star} \\
{[0.075]}\end{array}$ & $\begin{array}{c}0.084 \\
{[0.062]}\end{array}$ & $\begin{array}{l}0.106^{*} \\
{[0.055]}\end{array}$ & $\begin{array}{c}0.128^{\star \star \star} \\
{[0.049]}\end{array}$ & $\begin{array}{c}0.117^{\star \star *} \\
{[0.036]}\end{array}$ & $\begin{array}{c}0.129^{\star \star *} \\
{[0.042]}\end{array}$ & $\begin{array}{c}0.116^{* * *} \\
{[0.029]}\end{array}$ & $\begin{array}{c}0.093^{* * *} \\
{[0.031]}\end{array}$ \\
\hline 1 if female & $\begin{array}{c}-0.366^{\star * *} \\
{[0.047]}\end{array}$ & $\begin{array}{c}-0.360^{\star * *} \\
{[0.039]}\end{array}$ & $\begin{array}{c}-0.355^{\star * *} \\
{[0.031]}\end{array}$ & $\begin{array}{c}-0.401^{\star * *} \\
{[0.027]}\end{array}$ & $\begin{array}{c}-0.369^{* * *} \\
{[0.024]}\end{array}$ & $\begin{array}{c}-0.335^{\star \star \star} \\
{[0.018]}\end{array}$ & $\begin{array}{c}-0.277^{\star * *} \\
{[0.021]}\end{array}$ & $\begin{array}{c}-0.223^{* * *} \\
{[0.015]}\end{array}$ & $\begin{array}{c}-0.126^{* * *} \\
{[0.016]}\end{array}$ \\
\hline 1 if single & $\begin{array}{l}-0.087 \\
{[0.153]}\end{array}$ & $\begin{array}{c}-0.008 \\
{[0.136]}\end{array}$ & $\begin{array}{l}-0.079 \\
{[0.113]}\end{array}$ & $\begin{array}{c}0.014 \\
{[0.100]}\end{array}$ & $\begin{array}{c}0.014 \\
{[0.090]}\end{array}$ & $\begin{array}{l}0.115^{\star} \\
{[0.067]}\end{array}$ & $\begin{array}{c}0.1 \\
{[0.078]}\end{array}$ & $\begin{array}{c}0.036 \\
{[0.056]}\end{array}$ & $\begin{array}{c}0.106^{*} \\
{[0.061]}\end{array}$ \\
\hline 1 if divorced or widowed & $\begin{array}{c}0.097 \\
{[0.081]}\end{array}$ & $\begin{array}{c}0.052 \\
{[0.069]}\end{array}$ & $\begin{array}{c}0.025 \\
{[0.058]}\end{array}$ & $\begin{array}{l}-0.003 \\
{[0.051]}\end{array}$ & $\begin{array}{l}-0.036 \\
{[0.046]}\end{array}$ & $\begin{array}{c}-0.03 \\
{[0.034]}\end{array}$ & $\begin{array}{c}{[0.06} \\
-0.039]\end{array}$ & $\begin{array}{c}-0.065^{\star *} \\
{[0.028]}\end{array}$ & $\begin{array}{c}-0.046 \\
{[0.029]}\end{array}$ \\
\hline 1 if 1 child & $\begin{array}{l}-0.078 \\
{[0.119]}\end{array}$ & $\begin{array}{c}0.023 \\
{[0.105]}\end{array}$ & $\begin{array}{l}-0.032 \\
{[0.087]}\end{array}$ & $\begin{array}{c}0 \\
{[0.077]}\end{array}$ & $\begin{array}{c}0 \\
{[0.069]}\end{array}$ & $\begin{array}{l}-0.009 \\
{[0.051]}\end{array}$ & $\begin{array}{c}-0.01 \\
{[0.059]}\end{array}$ & $\begin{array}{l}-0.035 \\
{[0.043]}\end{array}$ & $\begin{array}{c}0.015 \\
{[0.046]}\end{array}$ \\
\hline 1 if more than 1 child & $\begin{array}{c}0.002 \\
{[0.127]}\end{array}$ & $\begin{array}{c}0.137 \\
{[0.113]}\end{array}$ & $\begin{array}{c}0.046 \\
{[0.093]}\end{array}$ & $\begin{array}{c}0.056 \\
{[0.082]}\end{array}$ & $\begin{array}{c}0.07 \\
{[0.074]}\end{array}$ & $\begin{array}{c}0.046 \\
{[0.055]}\end{array}$ & $\begin{array}{c}0.017 \\
{[0.063]}\end{array}$ & $\begin{array}{l}-0.044 \\
{[0.046]}\end{array}$ & $\begin{array}{c}-0.002 \\
{[0.049]}\end{array}$ \\
\hline Service staff & $\begin{array}{c}-0.596^{\star \star \star} \\
{[0.077]}\end{array}$ & $\begin{array}{c}-0.679^{\star \star \star} \\
{[0.066]}\end{array}$ & $\begin{array}{c}-0.760^{\star \star \star *} \\
{[0.055]}\end{array}$ & $\begin{array}{c}-0.812^{\star \star \star} \\
{[0.049]}\end{array}$ & $\begin{array}{c}-0.803^{\star * \star} \\
{[0.044]}\end{array}$ & $\begin{array}{c}-0.758^{\star \star \star} \\
{[0.032]}\end{array}$ & $\begin{array}{c}-0.783^{\star \star *} \\
{[0.038]}\end{array}$ & $\begin{array}{c}-0.785^{\star \star \star} \\
{[0.026]}\end{array}$ & $\begin{array}{c}-0.803^{\star \star \star} \\
{[0.029]}\end{array}$ \\
\hline Engineers & $\begin{array}{c}0.079 \\
{[0.069]}\end{array}$ & $\begin{array}{l}-0.025 \\
{[0.059]}\end{array}$ & $\begin{array}{l}-0.087^{*} \\
{[0.048]}\end{array}$ & $\begin{array}{c}-0.085^{\star \star} \\
{[0.043]}\end{array}$ & $\begin{array}{c}-0.100^{* * *} \\
{[0.038]}\end{array}$ & $\begin{array}{c}-0.110^{\star \star \star} \\
{[0.028]}\end{array}$ & $\begin{array}{c}-0.138^{* * *} \\
{[0.033]}\end{array}$ & $\begin{array}{c}-0.159^{* * *} \\
{[0.023]}\end{array}$ & $\begin{array}{c}-0.159^{* * *} \\
{[0.025]}\end{array}$ \\
\hline Accountants & $\begin{array}{c}0.644^{\star \star \star} \\
{[0.140]}\end{array}$ & $\begin{array}{l}0.492^{\star \star \star} \\
{[0.121]}\end{array}$ & $\begin{array}{l}0.498^{\star \star \star} \\
{[0.099]}\end{array}$ & $\begin{array}{c}0.459^{\star \star \star \star} \\
{[0.088]}\end{array}$ & $\begin{array}{c}0.406^{\star \star \star} \\
{[0.078]}\end{array}$ & $\begin{array}{c}0.349^{\star \star \star *} \\
{[0.056]}\end{array}$ & $\begin{array}{c}0.271^{\star \star \star} \\
{[0.065]}\end{array}$ & $\begin{array}{l}0.188^{\star \star \star} \\
{[0.044]}\end{array}$ & $\begin{array}{c}0.05 \\
{[0.050]}\end{array}$ \\
\hline Managers & $\begin{array}{l}1.046^{\star * \star} \\
{[0.110]}\end{array}$ & $\begin{array}{l}0.845^{\star * *} \\
{[0.098]}\end{array}$ & $\begin{array}{l}0.726^{* * *} \\
{[0.082]}\end{array}$ & $\begin{array}{l}0.602^{* * *} \\
{[0.073]}\end{array}$ & $\begin{array}{c}0.595^{\star \star *} \\
{[0.065]}\end{array}$ & $\begin{array}{l}0.541^{* * *} \\
{[0.048]}\end{array}$ & $\begin{array}{c}0.528^{\star \star \star} \\
{[0.056]}\end{array}$ & $\begin{array}{c}0.513^{* * *} \\
{[0.040]}\end{array}$ & $\begin{array}{c}0.464^{* * *} \\
{[0.042]}\end{array}$ \\
\hline Constant & $\begin{array}{c}-1.895^{\star \star} \\
{[0.964]} \\
\end{array}$ & $\begin{array}{c}-0.679 \\
{[0.844]} \\
\end{array}$ & $\begin{array}{c}-0.375 \\
{[0.724]} \\
\end{array}$ & $\begin{array}{c}-0.504 \\
{[0.655]} \\
\end{array}$ & $\begin{array}{l}-0.526 \\
{[0.589]} \\
\end{array}$ & $\begin{array}{c}-0.672 \\
{[0.440]}\end{array}$ & $\begin{array}{c}-0.76 \\
{[0.528]} \\
\end{array}$ & $\begin{array}{c}-0.196 \\
{[0.392]} \\
\end{array}$ & $\begin{array}{c}0.452 \\
{[0.461]}\end{array}$ \\
\hline Observations & 3040 & 3040 & 3040 & 3040 & 3040 & 3040 & 3040 & 3040 & 3040 \\
\hline
\end{tabular}

Quantile regression estımates. Standard errors In brackets
${ }^{*}$ significant at $10 \%$; ${ }^{*}$ significant at $5 \%$; ${ }^{* *}$ significant at $1 \%$ 